\title{
War Elephants and Early Tanks: \\ A Transepochal Comparison of Ancient and Modern Warfare
}

\author{
ALARIC SEARLE
}

One of the most influential military historians of the twentieth century, and the first theorist of tank warfare, Major-General J.F.C. Fuller, maintained throughout his life an interest in ancient warfare. Alexander the Great, in particular, represented an ongoing field of enquiry in his consideration of military history from antiquity to the present on which he had begun to publish during the interwar period. ${ }^{1}$ Well into his eighties, Fuller wrote an analysis of Alexander the Great's qualities as a military leader. In the foreword, he asserted: 'Happily, in this study of Alexander's generalship I am not called upon to be a Quellenforscher, because the art of war - certainly in its essentials - was the same in Alexander's day as it is now.' ${ }^{2}$ Although certainly a controversial statement, it would be a mistake to dismiss this claim as the ill-considered speculations of a general in retirement - the concept which lay behind the book had matured in his mind over a thirty-year period. ${ }^{3}$ But one of the intriguing points here is that, for all he wrote about the precursors of the tank, he never saw war elephants in that

\footnotetext{
${ }^{1}$ See the following articles by J.F.C. Fuller: 'The Sieges of Alexander the Great', Royal Engineers Journal, 39 (March 1925), pp. 103-10; 'The Decisive Battles of Alexander the Great', Cavalry Journal, 15, Part I (April 1925), pp. 137-56, Part II (July 1925), pp. 331-45, Part III (October 1925), pp. 443-56; 'The Small Wars of Alexander the Great', Cavalry Journal, 17, Part I (January 1927), pp. 42-55, Part II (April 1927), pp. 184-99; 'The Grand Strategy of Alexander the Great', RAF Quarterly, 3, Part I (January 1932), pp. 1-17, Part II (April 1932), pp. 153-63.

2 J.F.C. Fuller, The Generalship of Alexander the Great (New Brunswick, NJ, 1960), p. 7.

${ }^{3}$ King's College London, Liddell Hart Centre for Military Archives (hereafter, LHCMA), Captain Sir Basil Liddell Hart Papers, LH 1/302/493, Fuller to Liddell Hart, 9 December 1959. For further details, see Brian Holden Reid, 'British Military Intellectuals and the Lure of Antiquity', in idem, Studies in British Military Thought: Debates with Fuller \& Liddell Hart (Lincoln, Nebr., 1998), pp. 206-28.
} 
role, viewing the tank essentially as a war machine and, hence, a human invention, marking a distinct departure from human and animal muscular power. ${ }^{4}$

Even the most recent studies on the history of the tank and military mechanization generally approach the subject as historians have done since the early writings of Fuller. The history of the tank is seen as, in essence, a history of the invention of a new weapon. In his most recent history of the tank, Richard Ogorkiewicz discusses the precursors very much in the same terms as Fuller. The 'origin of the species', as he puts it colourfully, lay in steampowered vehicles. While some inspiration for the invention of the tank was provided by H.G. Wells' short-story of 1903, 'The Land Ironclads', the vehicle of his imagination was only steam-powered, whereas around the same time the internal combustion engine became the true basis for making guns mobile. ${ }^{5}$ Bruce Gudmundsson in his study of 'armour', also begins with the invention of machines, although he does include the development of armoured cars, and combines this dimension with the importance of ideas and combined-arms formations. ${ }^{6}$ Markus Pöhlmann, on the other hand, offers a different perspective, identifying military culture as an explanation for German attitudes before July 1914, and during the war, to military technology. He argues that the German High Command adopted a rational approach, best described as that of the 'later adopter'; there was little point in investing resources in largely untried and very new technology until it was clear that it offered a viable alternative to existing weapons and methods. ${ }^{7}$

\footnotetext{
${ }^{4}$ J.F.C. Fuller, Tanks in the Great War 1914-1918 (London, 1920), esp. pp. 297-307; see also, Anon. [J.F.C. Fuller], 'The Influence of Tanks on Military Operations', Ministry of Munitions Journal, 2, No. 25 (December 1918), pp. 346-48.

${ }^{5}$ Richard M. Ogorkiewicz, Tanks: 100 Years of Evolution (Oxford, 2015), pp. 11-21. For another example of the traditional explanations of 'origins', see David Fletcher, 'The Origins of Armour', in J.P. Harris and F.N. Toase (eds.), Armoured Warfare (London, 1990), pp. 5-26.

${ }^{6}$ Bruce Gudmundsson, On Armor (Westport, CT, 2004), pp. 1-33.

${ }^{7}$ Markus Pöhlmann, Der Panzer und die Mechanisierung des Krieges: Eine deutsche Geschichte 1890 bis 1945 (Paderborn, 2016), pp. 19-48, and, idem, 'Images of War, Armament and Mechanization in Imperial Germany, 1880-1914', in Alaric Searle (ed.), Genesis, Employment, Aftermath: First World War Tanks and the New Warfare, 1900-1945 (Solihull, 2015), pp. 13-30.
} 
Regardless of whether one looks to scholarly studies of the history of mechanization, or more popular works, the tank has usually been placed within a narrative which sees its invention as a 'turning point' in the history of warfare, a 'revolution' in methods and the start of a 'new epoch'. ${ }^{8}$ Thus, despite occasional passing references to war elephants - such as, that by the reign of Ptomely II (285-246 BC), they were 'essential war machines, the armoured tanks of their day ${ }^{9}$ - no serious consideration has been given to a comparison between the employment of elephants and tanks in war. A recent revival in interest in the history of strategy, however, suggests that more serious thought could be invested in considering whether there are broad principles of strategy which exist as apolitical entities, independently of epoch, political system and cultural attitudes to warfare: ${ }^{10}$ and, one route into this complex issue could be through a comparison of war elephants and tanks.

Perhaps because J.F.C. Fuller, the military historian one would have thought most likely to draw parallels between war elephants and tanks, never drew any such comparisons, possible similarities between tanks and war elephants remain unexplored territory for military historians. ${ }^{11}$ Still, the similarities do seem to be substantial enough to justify further investigation. War elephants, which were employed on battlefields from ancient times well into the middle ages, and which were used as heavy assault weapons, can be compared with some of the tanks used in the first half of the twentieth century. War elephants were mobile,

\footnotetext{
${ }^{8}$ Among other precursors of tanks which have been mentioned in the literature by 'tank pioneers', early advocates and more popular works are war chariots and knights in armour: E.H. Tennyson D'Encourt, British Tanks, paper read at meeting of the British Association for the Advancement of Science, Bournemouth, 10 September 1919 (London, 1919), p. 1; B.H. Liddell Hart, 'Medieval Cavalry and Modern Tanks', English Review, 40 (July 1925), pp. 83-96; and, H.C.B. Rogers, Tanks in Battle (London, 1965), pp. 11-30, who does mention war elephants, but whose account is entirely descriptive and does not draw comparisons with tanks. 9 Jacke Phillips, 'Punt and Aksum: Egypt and the Horn of Africa', Journal of African History, 38 (November 1997), pp. 423-57, quote, 446-47. See also the comments in J. Peddie, The Roman War Machine (Stroud, 1994), pp. 86-87.

${ }^{10}$ Some recent studies of strategy from a military-historical perspective are: Beatrice Heuser, The Evolution of Strategy: Thinking War from Antiquity to the Present (Cambridge, 2010); John Stone, Military Strategy: The Politics and Technique of War (London, 2011); Lawrence Freedman, Strategy: A History (New York, 2013); Hew Strachan, The Direction of War: Contemporary Strategy in Historical Perspective (Cambridge, 2013).

${ }^{11}$ It is curious that probably the first comparison of the two weapons was drawn in a satirical poem, published in a German publication, Kladderatsch, on 5 November 1916. It compared Hannibal's elephants with 'Haig's tanks', but was largely intended to ridicule the new weapon. Pöhlmann, Mechanisierung des Krieges, p. 112.
} 
projectiles could be fired directly from them into the enemy infantry in close proximity, while the elephants could exert considerable psychological effect on their opponents. These factors are but some of the more obvious parallels which can be drawn between war elephants and early tanks.

Any attempt to compare two very different 'weapons systems', each operating at different stages of military technological development, and within radically different societal contexts and alliance systems, will immediately face questions about methodology. Comparative historical analysis, itself, has been for many years the preserve of sociologists and political scientists, very often interested in quantitative approaches. Political parties, economic trends, ideologies and revolutions are among some of the concerns of their research agendas. ${ }^{12}$ Within the overlapping fields of military history and 'war and society', comparative studies have focused on combat power, military effectiveness and societies at war, though some work on military doctrine has also been undertaken. The key point here is that this work usually compares relatively similar societies, armies, concepts and mentalities within the same historical era. ${ }^{13}$

This comparative investigation will, however, attempt to draw comparisons which cut dramatically across historical epochs. The basis for this will not only be to investigate further interesting parallels to be found between ancient and modern warfare, but the 'device' of referring to both war elephants and tanks as 'weapons systems' will provide the basis for the comparison. Although the reader, like the theatre audience, is being asked to 'suspend belief' in the interests of the comparison, there is some justification for referring to war elephants

\footnotetext{
12 Some good expositions of approaches can be found in James Mahoney \& Dietrich Rueschemeyer (eds.), Comparative Historical Analysis in the Social Sciences (Cambridge, 2003).

${ }^{13}$ Among the best examples of some of these comparative approaches are: Allan R. Millett \& Williamson Murray (eds.), Military Effectiveness: Vol. 1: The First World War (Cambridge, 1998); Alexander Watson, Enduring the Great War: Combat, Morale and Collapse in the German and British Armies, 1914-1918 (Cambridge, 2008); Barry R. Posen, The Sources of Military Doctrine: France, Britain, and Germany between the World Wars (Ithaca \& London, 1984); Elizabeth Keir, Imagining War: French and British Military Doctrine between the Wars (Princeton, NJ, 1997); Martin van Creveld, Fighting Power: German and U.S. Army Performance, 1939-1945 (Westport, CT, 1982); and, Dietmar Süß, Tod aus der Luft: Kriegsgesellschaft und Luftkrieg in Deutschland und England (Munich, 2011).
} 
and tanks - albeit very loosely - as 'weapons systems'. While there appears to be no universally accepted definition in international law, according to one offered by the Geneva Academy of International Humanitarian Law and Human Rights:

A weapons system is a device or coordinated set of devices or objects that consists of one or more weapons and a means of delivery as well as integral equipment and materiel. A weapons system is distinguished from a weapon in that while it incorporates one or more weapons in many instances it can also be used for other purposes than killing, injuring, disorienting, or threatening a person or inflicting damage on a physical object. For instance, an aircraft can conduct surveillance and a ship can transport personnel and materiel. ${ }^{14}$

Thus, a tank usually mounts a cannon and a machine-gun, or affords the crew the ability to supplement the firepower on the vehicle itself, yet it can be used to transport supplies, wounded soldiers or communications equipment. By the same logic, a war elephant could transport archers into battle, for instance, but it could also be employed for logistic purposes. While the term weapons system not only suggests the 'platform' for the employment of more than one weapon, the 'system' requires - due to its complexity - a form of support structure different to that of the individual soldier with a hand-held weapon. Finally, for the purposes of the comparison, it needs to be pointed out that the symbolism with which an individual weapon can be invested is of a rather different nature to a weapons system, as the latter is operated by a 'crew' rather than one soldier. ${ }^{15}$

In order to delve deeper into this subject, then, four comparisons will be undertaken: first, a general comparison of the two weapons systems; second, their employment in war; third, the tactical and operational functions of the two weapons; and, fourth, their role as

\footnotetext{
${ }^{14}$ http://www.weaponslaw.org/glossary/weapons-system; accessed 9 February 2017. According to the US Department of Defense Dictionary of Military and Associated Terms (edition of 15 December 2016), a 'weapon system' is: 'A combination of one or more weapons with all related equipment, materials, services, personnel, and means of delivery and deployment (if applicable) required for self-sufficiency.' See the online edition at http://www.dtic.mil/doctrine/new_pubs/dictionary.pdf, p. 253; accessed 9 February 2017. Thus, in contemporary military and security literature, the terms 'weapon system' and 'weapons system' are used with little real distinction drawn between the two. The latter term will be preferred throughout this article.

${ }^{15}$ On the symbolism of weapons in general, see Urte Evert, Die Eisenbraut: Symbolgeschichte der militärischen Waffe von 1700 bis 1945 (Münster, 2015).
} 
symbols of military and state power. This comparative exercise will provide a platform for an analysis of two related issues: on the one hand, why J.F.C. Fuller was so reluctant to draw any parallels between the two weapons; and, on the other, what general observations can be drawn from the comparison. Some final reflections will be offered on Fuller's claim that the essential elements of the art of war have not changed since ancient times, considering in turn what this transepochal analytical exercise suggests about the nature of strategy.

\section{The Two 'Weapons Systems'}

The basis for this comparison lies in some interesting parallels which can be drawn between war elephants and early armoured vehicles. Tanks built during the First World War, or improvised armoured vehicles, such as the 'Bison' in the Second World War, or home-made Kurdish armoured vehicles built in haste for use in combat against the so-called 'Islamic State', were all 'primitive' enough to enable a realistic comparison of these two 'weapons systems' to be undertaken. ${ }^{16}$ The first dimension to the comparison is that both weapons went through a process of development (although each at a different pace), which in its initial phase allowed relatively simple weapons to surprise an unprepared opponent, although the possibility of disaster was ever present. ${ }^{17}$ Where the comparison becomes particularly interesting is when we include the complexities of both weapons systems in relation to the interaction between the 'crews' and the weapon itself. The first difficulty for the driver of the

\footnotetext{
${ }^{16}$ It could be argued that once armoured vehicles were equipped with, first, both cannon and machine-guns in their turrets, then subsequently the $75 \mathrm{~mm}$ cannon (Panzer IV) and 76mm cannon (T-34), their technological development had reached a point whereby their main strength was their long-range gun. Thus, the comparison can only be undertaken in the case of vehicles in the first phase of the tank's evolution.

${ }^{17}$ On 1 October $331 \mathrm{BC}$, for example, according to one version, a group of elephants intended for use by Darius against Alexander was unable to take to the field as they had been awake all night; it has been speculated they had become extremely restless, which had disturbed Darius' cavalry, so they needed to be removed from the battle. John M. Kistler, War Elephants (Lincoln, Nebr., \& London 2007), pp. 28-31. An instance of disaster in the employment of an untried tank unit was the first employment of 12 Renault FT-17 tanks by the Spanish Army on 18 March 1922 against Rif tribesmen. The tanks advanced beyond the infantry, some of their machineguns jammed, two broke down, tribesmen pushed knives through the vision slits, and the other machines were forced to withdraw. J.E. Alvarez, 'Tank Warfare during the Rif Rebellion, 1921-1927', Armor, 106 (Jan/Feb 1997), pp. 26-28.
} 
elephant, the mahout, lay in giving signals to the animal so that it could be controlled in battle. In First World War tanks, complexity was to be found in the challenges of operating the gun or machine-guns, and in steering. In other words, training formed the basis for successful employment in war in the case of both weapons. ${ }^{18}$

To consider the subject in more detail, let us begin with the war elephant. Unlike the situation today, where the elephant is threatened with extinction, caused by illegal hunting and a disappearing habitat, in the ancient world there were plenty of elephants which could be caught. For the purposes of war, wild elephants were preferred over those which had been raised in captivity because an elephant taken from the wild was more aggressive and far cheaper than a calf which took over twenty years before it had fully grown; and, anyway, after twenty years it had become too domesticated, so could only be used for the carrying of war material or supplies. The necessity of employing an elephant captured in the wild meant that the temperament of the animal was an essential prerequisite for its use in battle. In addition, since elephants demonstrated a high level of intelligence, they could be trained to perform a range of tasks. ${ }^{19}$

In contrast to the other animal frequently employed in war in antiquity, the horse, which could be trained for clashes on the battlefield, elephants have been the only animal which have fought for humans in war as opposed to performing a few basic tasks. ${ }^{20} \mathrm{We}$ are talking here principally about male elephants. In addition to charging opponents, which was all horses could perform, elephants could trample enemy soldiers, at the same time they could

\footnotetext{
${ }^{18}$ On the challenge of steering the British Mark I, see D.G. Browne, The Tank in Action (London, 1920), pp. 1921; for the training of the British Tank Corps in France, J.F.C. Fuller, Memoirs of an Unconventional Soldier (London, 1936), pp. 87-112, and, University Archives \& Special Collections, Rutgers University, NJ, MajorGeneral J.F.C. Fuller Papers, box 14, HQ, Tank Corps, G.S.943. Instructions for the Training of the Tank Corps in France (British Army Printing \& Stationary Services, 1 December 1917); for the training of elephants, Kistler, War Elephants, pp. 9-13.

${ }^{19}$ Kistler, War Elephants, pp. ix-xii; C.A. Spinage, Elephants (London, 1994); Gary Haynes, Mammoths, Mastodonts, and Elephants: Biology, Behaviour, and the Fossil Record (Cambridge, 1991); Edward B. Barbier, Elephants, Economics, and Ivory (London, 1990).

${ }^{20}$ For a complete overview of the employment of animals in war, see: Jared Eglan, Beasts of War: The Militarization of Animals (St Raleigh, NC, 2015); and, Rainer Pöppinghege (ed.), Tiere im Krieg von der Antike bis zur Gegegenwart (Paderborn, 2009), esp. pp. 7-31.
} 
employ their tusks, trunks, head, legs and the mass of their bodies in close combat. When charging, they could be remarkably fast. But what characterizes elephants in the history of war has been their capacity to follow a variety of relatively complex instructions from their mahout. ${ }^{21}$ In fact, the interaction between mahout and elephant can be compared with the tasks performed by a fighter pilot or tank driver.

While the intention here is not to overplay the comparison, it is possible to discern some of the contours of the theories of the sociologists of technology in relation to the process of a soldier controlling a complex, modern, mobile weapons system in the relationship between mahout and war elephant. Indeed, parallel to the observations of historians of technology, that the pilot or tank commander never had absolute control over the technology he was operating, the mahout likewise could never be certain that the elephant would follow all his instructions during a battle. Furthermore, with the emergence of a new military elite of technicians through air squadrons and tank divisions in the mid-twentieth century, characterized by specific knowledge and skills, a comparison can be made with the 'special units' of elephant troops in armies of the antique, not least of all as the elephant had the capacity to render chariots obsolete. ${ }^{22}$

A further and important basis for a comparison of elephants and tanks can be identified in the weapons and armour with which some elephants began to be equipped. At first, this was simply the positioning of archers and spear throwers on the back of the animals, which directed their projectiles at enemy infantry. Later, at the latest by the first century BC, baskets or 'towers' (howdahs) were fixed on the backs of the pachyderms, so the archers

\footnotetext{
${ }^{21}$ Kistler, War Elephants, pp. 9, 23, 193-94, 214-16. Biologists have for many decades debated possible parallels between human and animal aggression, but it is generally held that aggressiveness in animals is very different to that which is found in homo sapiens. See, for instance, Irenäus Eibl-Eibesfeldt, The Biology of Peace and War: Men, Animals and Aggression (London, 1979).

${ }^{22}$ Werner Rammert, Technik und Sozialtheorie (Berlin, 1998); Trevor Pinch \& Nelly Oudshoorn (eds.), How Users Matter: The Co-construction of Users and Technology (London, 2003); Jost Halfmann (ed.), Theoriebausteine der Techniksoziologie (Frankfurt am Main/New York, 1995); and, Gavin de Beer, Hannibal: The Struggle for Power in the Mediterranean (London, 1974), p. 101.
} 
were not so precariously perched on the elephant when taking aim, not to mention giving them a more protected firing platform. Still later, armour was developed to provide protection for the head of the elephant. Metal strips were sometimes bound around the legs of the animal so that one of their most vulnerable points was covered. Hence, although the term 'weapons system' can only be given in inverted commas in the case of war elephants, some of the features in the early development of the tank can be recognized, not least of all in the continual improvement in protection, best described as 'up-armouring'. ${ }^{23}$

Of course, the technical development of the first tanks during the Great War was more rapid, measurable in a period of less than four years, even if characterized by the limitations of the first combat machines. The first British tank, the Mark I, had a theoretical speed of $3.65 \mathrm{mph}$, but travelled more slowly over open terrain. Its successor design, the Mark IV was unable to achieve any improvements in terms of speed, even if the Mark V did manage to reach $4.6 \mathrm{mph}$. In other words, elephants were still able to outstrip the early tanks in terms of rapidity of advance. Nonetheless, if one looks at some of the Kurdish home-made vehicles which have appeared in the fighting in Syria since 2011 based around rubbish-disposal lorries and other civilian vehicles, higher speeds were achieved, albeit combined with modest firepower. This said, the British Medium A 'Whippet' tank which appeared in France in 1918 achieved a speed of $8.3 \mathrm{mph}$. There were other armoured vehicles in this period - the Rolls Royce Armoured Car, for example, had a maximum speed on roads of $45 \mathrm{mph}$ - which were considerably faster than tanks, but unable to negotiate rough terrain. ${ }^{24}$

The French produced three types of tank during the First World War: the Schneider CA1 was slightly faster than the British heavy tanks, with a speed of $5 \mathrm{mph}$; the SaintChamond managed $8 \mathrm{mph}$ on road, less over rough terrain; even the light Renault FT-17,

\footnotetext{
${ }^{23}$ Kistler, War Elephants, pp. 21-23, 27, 50-51, 157-58, 195.

${ }^{24}$ David Fletcher, British Mark I Tank 1916 (Oxford, 2004), p. 29; David Fletcher, British Mark IV Tank (Oxford, 2007), p. 28; David Fletcher, Mark V Tank (Oxford, 2011), p. 27; and, Bryn Hammond, 'Practical Considerations in British Tank Operations on the Western Front, 1916-1918', in Searle (ed.), First World War Tanks, pp. 31-56.
} 
which was much faster on roads, could only manage $4.3 \mathrm{mph}$ over the battlefield. The German A7V, of which only twenty were ever produced, managed $15 \mathrm{~km} / \mathrm{h}$ on roads, but had poor cross-country mobility. The French Schneider and Saint-Chamond suffered from a variety of technical defects, while the A7V could topple over if it drove up an incline at the wrong angle. Thus, these weaknesses indicate parallels with war elephants in battle, not least of all the progressive attempts to add armour and counteract some of the other vulnerabilities. $^{25}$

The conditions for the crews of all First World War tanks, whether British, French or German, were taxing. In the case of British tanks, the Marks I, IV and V, eight men had to fight and operate the tank in cramped conditions, the earlier models subjecting them to carbon monoxide poisoning and intense heat. During combat action, enemy fire made it too dangerous to open any of the hatches. Furthermore, driving a tank was extremely strenuous: in the British machines, the driver sat at the front to steer, while the commander attempted to give signals through sign language, while in the rear of the machine two crew members operated the gears. While source material for ancient warfare is obviously limited in comparison to documents from the Great War, it seems reasonable to assume that communication between soldiers positioned on top of an elephant would have been at least for some of the time reduced to hand signals due to the general tumult of battle. ${ }^{26}$ Interestingly, a similar solution to the communications problem was developed in the case of both weapons systems: by the sixth century BC, one in ten war elephants had become a signal

\footnotetext{
${ }^{25}$ Olivier Lahaie, 'The Development of French Tank Warfare on the Western Front, 1916-1918', in Searle (ed.), First World War Tanks, pp. 57-79; S.J. Zaloga, The French Renault Light Tank (London, 1988); S.J. Zaloga, German Panzers 1914-1918 (Oxford, 2006); and, Ralf Raths, 'From the Bremerwagen to the A7V: German Tank Production and Armoured Warfare, 1916-1918', in Searle (ed.), First World War Tanks, pp. 80-107. ${ }^{26}$ Bryn Hammond, 'Practical Considerations in British Tank Operations', pp. 31-56, esp. 39-46.
} 
elephant; in the second half of 1917, both the British and the French employed signal tanks for the first time during Third Ypres and the Battle of Malmaison, respectively. ${ }^{27}$

So, it can be asserted, that the limitations experienced in the early tank actions do suggest that a comparison of early twentieth-century military technology with war elephants can be made in terms of the experience of the crews and drivers in battle. Both 'weapons systems' experienced certain limitations, obviously taking into account the differing levels of military technological development in each case, but both still possessed certain advantages over the other arms if employed correctly and especially whenever surprise could be exploited. Both 'weapons systems' also possessed enough flexibility to be able to influence specific encounters on the battlefield, not to mention creating a psychological advantage for the attacker. From general observations, the comparison now needs to move to more specific details, in the first instance to the actual employment of both weapons in war.

\section{Employment in War}

Among the most significant battles ${ }^{28}$ in which elephants were employed were Arbela in 331 BC, where Darius Codomannus reputedly used 15 elephants against Alexander the Great. Five years later Porus employed around 200 elephants in a battle against Alexander near Chillianwalla; yet despite furious fighting, Alexander emerged victorious. During the battle of Ipsus in $301 \mathrm{BC}, 400$ elephants took part in the fighting when Seleucus, one of Alexander's generals, fought against Demetrius. Seleucus successor, Antiochus I, created a mass panic among the cavalry of the Gauls (a force of around 40,000) in 280 BC using pachyderms; in 273 BC, at the 'Elephant Victory', he reputedly only used 16 elephants. Some

\footnotetext{
${ }^{27}$ Kistler, War Elephants, p. 23; Brian N. Hall, 'The Development of Tank Communications in the British Expeditionary Force, 1916-1918', in Searle (ed.), First World War Tanks, pp. 136-62, esp. 148-52; Tim Gale, The French Army's Tank Force and Armoured Warfare in the Great War: The Artillerie Spéciale (Farnham, 2013), p. 88.

${ }^{28}$ Useful as an introduction to battles are: the reprinted article, Major-General Sir John Moore, 'Elephants in War', Canadian Veterinary Journal, 27 (1986), pp. 312-13; and, Duncan Head, Armies of the Macedonian and Punic Wars: Organisation, Tactics, Dress and Weapons (Goring-on-Sea, 1982), pp. 35, 63-84.
} 
of the greatest successes of elephants were based on their effects on horses. The Carthaginians first encountered elephants in Sicily; they must have become convinced of their value as by $262 \mathrm{BC}$ they had established their own elephant forces. During the first Punic Wars, the army of the Carthaginians used elephants against the Romans near Palermo, who defended themselves against the animals with burning arrows. This created such complete panic among them that they trampelled many of their own infantry to death. Zama in 202 BC saw a further victory of the Romans against elephants, this time in battle against Hannibal.

It is also worth mentioning that the use of elephants in war has been identified in India as early as $1000 \mathrm{BC}$, where they were frequently employed by rulers in Assam. Moreover, the method of directing an elephant through a stick with a hook attached to the end began in India; indeed, the utilization of elephants was much more pronounced there than in the West. When war elephants had ceased to be used in the Mediterranean region, they continued to be employed in south Asia in armies for logistic purposes, especially in mountainous areas, where they were used for transport across passes and rivers. One reason for the use of the animal may have been that the climate and terrain in India was not conducive to the breeding of horses, so the large numbers of elephants available guaranteed their place in armies. Among the examples of the successful employment of elephants in the region are, for instance, when Kaiser Cyrus conquered the Punjab in 331 BC. It has been speculated that Alexander's expansion east of the Punjab was not continued due to the existence of an army of 8,000 elephants which was possessed by Kaiser Nanda. ${ }^{29}$

\footnotetext{
${ }^{29}$ Kaushik Roy, 'Use of Elephants in Indian Warfare (1000 BCE - 1943 CE)', in Daniel Coetzee \& Lee W. Eysturlid (eds.), Philosophers of War: The Evolution of History's Greatest Military Thinkers. Volume 1: The Ancient to the Premodern World, 3000 BCE - 1815 CE (Santa Barbara, CA, 2013), pp. 390-94.
} 
Not nearly enough is known about war elephants in ancient and medieval China, but it seems they were employed far less than in India. ${ }^{30}$ Apparently, the Shang Dynasty made use of war elephants before $1000 \mathrm{BC}$, but their employment remained geographically restricted. In $506 \mathrm{BC}$, the Chu army attempted to break a siege by the Wu army by attaching lighted torches to the tails of elephants; but this stratagem failed. In fact, in northern China, elephant populations began to decline. Hence, although herds of wild elephants could still be observed roaming in the sixth century, only a few other examples of military use have been discovered before the tenth century, perhaps because sound counter-measures were known. During the campaign against the Champa kingdom in Spring 605 AD, a Sui army faced war elephants in its drive south; following initial reverses, covered pits were employed to ensnare the elephants, while crossbows were used successfully against them. The only army to have maintained them was in the state of Southern Han (917-971 AD), with its capital in Canton. They successfully employed an elephant corps against the state of Chu in 948, but were defeated by Sing cross-bowmen in 971 . In the 13th and 14th centuries, the Mongol Khans, with their capital at Peking, maintained several thousand elephants as part of their military establishment. Thereafter, their main use appears to have been for ceremonial duties. It was reported by a nineteenth-century British writer, for instance, that, in 1598, the Emperor in Peking had proudly displayed sixty elephants to visitors, all extravagantly clothed and decorated, but these were obviously for ceremonial purposes. ${ }^{31}$

In the wake of the Roman advances into Parthia and Mesopotamia (53-119 AD), the emergence of the Sassanid Persian Empire (224-651 AD) saw further employment of war

\footnotetext{
30 李章星 [Zhiang-xing Li], 《中国古代 “象兵” 沿革考》 ['Research on “Elephant Troops” in Ancient China'], 河北北方学院学报（社会科学版） [Journal of Hebei North University (Social Science Edition)], 30 (December 2014), pp. 51-55, which emphasizes the lack of research among Chinese historians into the subject.

${ }^{31}$ Kistler, War Elephants, pp. 21, 206; Edward H. Schafer, 'War Elephants in Ancient and Medieval China', Oriens, 10 (December 1957), pp. 289-91; David A. Graff, Medieval Chinese Warfare, $300-900$ (London \& New York, 2002), p. 145; and, John Ranking, Historical researches on the wars and sports of the Mongols and Romans in which elephants and wild beasts were employed or slain, and the remarkable local agreement of history with the remains of such animals found in Europe and Siberia (London, 1826), pp. 90-92.
} 
elephants. The Sassanians, who inherited parts of their military system from the Persians, created their own elephant corps, although the shock troops were those of the heavy, armoured cavalry. Indian elephants tended to be deployed to the rear of their armies, although some evidence suggests they were also used in surprise attacks. The Sassanian army was a multi-ethnic force, including Iranians and Mongolian Chionite-Ephthalites; the elephant mahouts were from India. Clashes with Roman armies were frequent; at a battle at Suma (363 AD), elephants initially caused the dislocation of a Roman column, which was exploited by bowmen and lancers, but they were then driven off by reinforcements, suffering additional pachyderm losses in the process. The retention of the Sassanian elephant corps, and its continued employment, suggests that elephants must have continued to be useful, despite the importance of both heavy and light cavalry, up until the high water-mark of the Sassanid Persian Empire around $620 \mathrm{AD}$, not least of all for their symbolic value for the dynasty. ${ }^{32}$

The eventual disappearance of elephants from the battlefield was the result of specific tactical-technical developments; it seems likely that by the sixth century elephants' primary functions in war had been reduced to logistics and sieges. ${ }^{33}$ Arab armies, which mounted archers on horse-back, were too fast and mobile for the elephant formations from India. In June 712 AD, 6,000 Syrian cavalrymen annihilated Daher's elephant-dominated army. New bows had changed the tactical balance because arrows could now penetrate elephant hide. Moslem cavalry became much more effective through the invention of horse shoes which were nailed into place. Despite this development, elephants were still integrated by the Turco-Mongols into their army as they expanded into India to found the Mughal Empire. It was, however, the discovery of gunpowder which marked the end of the employment of war

\footnotetext{
${ }^{32}$ Peter Wilcox, Rome's Enemies (3): Parthians \& Sassanid Persians (Oxford, 1986), pp. 33, 38, 44; R.N. Frye, 'The Political History of Iran under the Sasanians', in Eshan Yarshater (ed.), The Cambridge History of Iran, Volume 3 (1): The Seleucid, Parthian and Sasanian Periods (Cambridge, 1983), pp. 116-80; Michael B. Charles, 'The Rise of the Sassanian Elephant Corps: Elephants and the Later Roman Empire', Iranica Antiqua, 42 (2007), pp. 301-46.

${ }_{33}$ Philip Rance, 'Elephants in Warfare in Late Antiquity', Acta Antiqua, 43 (2003), pp. 355-84.
} 
elephants in battle: the last large-scale appearance of elephants was on 5 November 1556 AD during the second battle of Panipat. ${ }^{34}$ Still, despite their decreasing use in the medieval period, war elephants played far more than merely a secondary role in ancient warfare.

If we turn to the appearance of tanks during the First World War, they were employed principally on the Western Front. The first combat action occurred on 15 September 1916, when just over 20 British tanks managed to leave the start line during the engagement at Flers-Coucelette during the Battle of the Somme in what was a first test for tanks. Although the success was modest, around 400 German infantrymen were captured. The first French tank action came on 16 April 1917 during the Battle of Chemin des Dames during the illfated Nivelle Offensive. Many tanks were put out of action by artillery fire, others had their technical deficiencies ruthlessly exposed in the course of the battle; in total, 57 tanks were lost. While the early actions brought rather poor results, the first mass attack of British tanks came on 20 November 1917 when the British III and IV Corps launched a bold attack in the direction of the major rail-junction at Cambrai. In total, 378 combat tanks were thrown into the battle; wide German trenches were overcome through the use of fascines, bundles of wood bound together and released from the nose of the tank into the trench to allow the tank to cross. Although the initial gains made by the British were largely negated by a daring German counter-attack, Cambrai demonstrated beyond all reasonable doubt the future possibilities of the new weapon. Thus, during the decisive battles of the Allied counteroffensives in the second half of 1918, tanks played a key role in breaking the resistance of the German Army on the Western Front. ${ }^{35}$

\footnotetext{
${ }^{34}$ Roy, 'Use of Elephants in Indian Warfare', pp. 390-94.

35 Trevor Pidgeon, The Tanks at Flers: An Account of the First Use of Tanks in War at the Battle of FlersCourcelette, the Somme, 15th September 1916 (Cobham, 1995); Gale, Artillerie Spéciale, pp. 33-59; Wilfred Miles, History of the Great War: Military Operations, France and Belgium, 1917. The Battle of Cambrai (London, 1949), passim; J.P. Harris \& Niall Barr, Amiens to the Armistice: The BEF in the One Hundred Days' Campaign, 8 August-11 November 1918 (London, 1998), pp. 87-143; and, for interesting perspectives on the limited employment of German tanks in 1918, Pöhlmann, Mechanisierung des Krieges, pp. 117-29.
} 
A handful of tanks were also tested during the Second and Third Battles of Gaza in Palestine in 1917. Although on both occasions only eight tanks were employed, the experience did demonstrate that tanks could be used under desert conditions. Furthermore, the British sent 150 tanks to the White Russian Army under General Anton Denikin during the Russian Civil War, 1919-21. Five Renault FT-17 tanks were also used in combined actions between French and Polish forces; these tanks were abandoned, captured later by the Red Army, and used as the basis for the creation of the Soviet tank industry which was built around the production of copies of the French tank. In fact, in the interwar period the Renault FT-17 was employed in several wars, including the Chaco War and the Spanish Civil War. These examples indicate that First World War tanks continued to be used after the conflict, in some cases against non-European forces. This use of tanks in combat against armies without tanks suggests a further justification for a comparison with war elephants. ${ }^{36}$

In the course of the Great War, the French produced around 800 Schneider and SaintChamond heavy tanks and more than 2,500 Renault FT-17 light tanks by 11 November 1918, whereas the British built in total 2,818 tanks of all types. Seen in relation to the manufacture of artillery pieces and shells, the production costs of the tanks were relatively low by comparison. ${ }^{37}$ Thus, if for a moment we leave India with its large numbers of war elephants out of the equation, there are comparisons which can be drawn between elephants' use in ancient warfare and tanks in the era of the Great War in terms of their numbers vis-à-vis the size and fiscal value of the other parts of the respective armies. Enough elephants and tanks were available that they frequently made important tactical contributions in combat and, at the same time, they could on occasions decide battles. Still, in both cases, historians are not in

\footnotetext{
${ }^{36}$ Steven J. Main \& Alaric Searle, 'Beyond the Western Front: Tanks in Palestine and Russia, 1916-1921', in Searle (ed.), First World War Tanks, pp. 163-90; James S. Corum, 'The Chaco War, 1932-1935', Quarterly Journal of Military History, 21 (Summer 2009), pp. 52-65.

${ }^{37}$ Gale, Artillerie Spéciale, pp. 227-30, 235-44; War Office, Statistics of the Military Effort of the British Empire during the Great War 1914-1920 (London, 1920), pp. 178-80, 219, 479.
} 
agreement as to how 'decisive' both weapons systems were in specific battles in which they played an important role, and what the ultimate effect was on a campaign.

There is one final point in relation to a broad comparison which is worth making in relation to the employment of both weapons in war: namely, there are very few examples of elephant vs. elephant actions in the ancient world (they did occur but were the exception rather than the rule), while the First World War saw only one tank vs. tank engagement. At the Battle of Paraetacene in 317 BC, the army of Antigonus the One-Eyed took to the field against Eumenes. The former's army deployed 28,000 heavy infantrymen, 5,500 light infantry, approximately 10,600 cavalry, and 64 war elephants, whereas the latter possessed 17,000 heavy infantry, 18,000 light infantry, 6,300 cavalry, 10,000 archers and 125 war elephants. The overall result of the actual fighting could be summarized as a 'draw', although the following year there was a different outcome at the Battle of Gabiene, which lies in what is now Iran. At this battle, the numerical advantage was held by Antigonus, although he employed 65 elephants to the 114 of Eumenes; again, in terms of actual fighting, the results were initially inconclusive. In the first battle, the elephant vs. elephant combat was not decisive, but in the second, Eumenes elephants were decisively defeated despite their numerical superiority. ${ }^{38}$

While these two engagements were large, pitched battles, the first tank vs. tank encounter in April 1918 was a small tactical engagement at Villers-Bretonneux. The Germans had attacked through the small French town with two A7V tanks, while four others were engaged to the south. The two German machines which had advanced into the town were engaged by three British Mark IV machines. The lead German tank knocked out two female tanks quickly, but was then hit three or four times by one male Mark IV, although the latter

\footnotetext{
${ }^{38}$ Kistler, War Elephants, pp. 47-53; Diodorus Siculus (80-20 BC), 'The Armies of Eumenes and Antigonus at the Battle of Paraetacene (Autumn 317)', in M.M. Austin (ed.), The Hellenistic World from Alexander to the Roman Conquest: A Selection of Ancient Sources in Translation (Cambridge, 2006), pp. 78-80; Head, Armies, pp. 68-69.
} 
was put out action by shell fire. The German machines then withdrew. The chief interest in the rather inconclusive action was the different lessons drawn by both sides. For the British, their after-action reports noted that the Germans might not make the same mistake in the future of employing small numbers of tanks, whereas the Germans were not in any position to organise a mass tank attack given that their complete inventory in the war was only 200 tanks, not to mention a host of organizational, training and supply problems. ${ }^{39}$ But both Paraetacene and Villers-Bretonneux demonstrate the difficulty of drawing clear lessons from the first instances of elephant vs. elephant and tank vs. tank combat.

\section{Tactical and Operational Functions of the 'Weapons Systems'}

In an attempt to compare war elephants with early tanks, it should be noted that many of the details surrounding ancient battles are contested by historians. This goes so far that one of the most famous military leaders who used elephants has enjoyed a reputation which is built in part upon a text fragment which is still being argued over. Whether Hannibal equipped elephants with towers hangs on the credibility of a fragment, which some historians of the antique consider a part of Polybius' Historiae, while others have cast doubt upon it. As Hannibal has been described in many works as having led an army of invasion with 37 elephants during the first phase of the Second Punic War, an army which also employed elephants during the Battle of Trebia in 218 BC and later in 202 BC used elephants unsuccessfully at Zama, the question of the use of towers on the backs of the animals is more than simply a minor detail. ${ }^{40}$

\footnotetext{
${ }^{39}$ Tank Museum Archive and Research Library, Bovington (hereafter, TMARL), Major-General J.F.C. Fuller Papers, Private Journal of Lt. Colonel J.F.C. Fuller relative to the Expansion and Employment of the Tank Corps, December 1917 to July 26, 1918, B46, German Tank Operations, Villers-Bretonneux, 24 April 1918, and H.J. Elles to General Staff, GHQ, 26 April 1918; Pöhlmann, Mechanisierung des Krieges, pp. 99-110.

${ }^{40}$ Philip Rance, 'Hannibal, Elephants and Turrets in Suda $\theta 438$ [Polybius Fr. 162B] - An Unidentified Fragment of Diodorus', Classical Quarterly, 59 (1) (2009), pp. 91-111. On the problematic nature of Polybius as a military historical source more broadly, see Martin Samuels, 'The Reality of Cannae', Militärgeschichtliche Mitteilungen, Nr. 47, 1/1990, pp. 7-29, esp. 7-10.
} 
Hence, given the lack of certainty about many of the central facts, the main section of this comparison will be based around the broad area of tactical and - to a lesser extent 'operational' functions. Where comparisons are perhaps of least value is obviously in battles where relatively few war elephants or tanks were employed. So, for this reason, probably one of the first recorded battles involving elephants which occurred outside India is of rather limited worth. At the battle of Arbela (also referred to as Gaugamelan) in $331 \mathrm{BC}$, the Persians under Darius apparently positioned 15 elephants at the front of their army, in the centre, as they prepared to do battle with Alexander. The Persians were able to deploy 200 chariots, 40,000 cavalry, whereas Alexander had 7,000 cavalry and 40,000 infantry. Elephants were unable to prevent the victory scored by Alexander because his attacks were fast and unexpected. This example could be compared with the first tank attack launched by the British Army on 15 September 1916 when 48 tanks were available at the start of the attack; of these, 36 reached the start-line; 30 actually left the start-line; and, since only 21 were involved in any combat, the degree of success achieved was decidedly limited. ${ }^{41}$

But if we consider now the actual tactical functions of both weapons systems, the first observation which can be made lies in the surprise and shock effect which was caused by both weapons during an attack, especially at the point of contact. German troops on the Western Front sometimes reported the breakthrough of tanks, even when none had taken place. $^{42}$ It is obvious that elephants caused similar outbreaks of panic during campaigns in the ancient world. Until serious counter-measures were developed, both war elephants and tanks caused severe problems for infantry when facing these new 'weapons systems', although the

\footnotetext{
${ }^{41}$ J.F.C. Fuller, Decisive Battles of the Western World and their Influence upon History. Vol. I: From the Earliest Times to the Battle of Lepanto (London, 1954), pp. 87-114; J.P. Harris, Men, Ideas and Tanks: British Military Thought and Armoured Forces, 1903-1939 (Manchester, 1995), p. 65. It is worth noting that an intelligent case has been made that elephants may not have actually been employed on the battlefield at all. See Michael B. Charles, 'Alexander, Elephants and Gaugamelan', Mouseion: Journal of the Classical Association of Canada, Series III, Vol. 8 (2008), pp. 9-23.

${ }^{42}$ For an example involving the German 27th Infantry Division near Arras in April 1917, see Alexander Fasse, Im Zeichen des „Tankdrachen“. Die Kriegführung an der Westfront 1916-1918 im Spannungsverhältnis zwischen Einsatz eines neuartigen Kriegsmittels der Alliierten und deutschen Bemühngen um seine Bekämpfung, Dr.phil. Dissertation, Humboldt-Universität zu Berlin, 2007, pp. 169-70.
} 
first attacks were quite primitive. In the case of war elephants, it was discovered that aggressiveness could be created by giving the animals alcohol or through loud noises. Initially, elephants wore no protective armour and the driver could only attempt to frighten enemy troops, cavalry and chariots through the size of the beast, or have the elephant trample the opponents. There is a parallel of sorts with the early First World War tanks, which had extremely thin armour, with limited visibility for the crew members inside. The best method of attack was for the tanks to flatten barbed-wire, then crush opposing infantry or machinegun them. The psychological effect of the early attacks was often much higher than the actual tactical effect; and, it was sometimes heightened by the slow speed at which the tanks advanced. In the case of war elephants, the crushing of enemy infantry under their feet must have caused intense fear on occasions. ${ }^{43}$

Given the primitive form of the assaults conducted by war elephants and the first tanks, it was not long before effective counter-measures began to be developed. When facing war elephants, the simplest methods were either to hack off the animal's trunk, or to cut through the tendons on the back of its legs, causing it to collapse. Another tactic was to use fire or create loud noises during battle in order to startle them. In anti-tank warfare on the Western Front, and in the two decades after the war, there were two basic approaches: first, to dig anti-tank ditches so that the machines would become stuck, or to create other forms of physical obstacles; second, to use artillery firing over open sights. Again, the comparison does seem to offer obvious parallels: in the case of both anti-elephant and anti-tank warfare, it was essential to have well-trained troops, either infantry willing to close with the elephants in combat, or artillerymen able to hold their nerve long enough to allow the tanks to come within close enough range to increase the chance of a direct hit. ${ }^{44}$

\footnotetext{
${ }^{43}$ Kistler, War Elephants, pp. 8-9; Hammond, 'Practical Considerations in British Tank Operations', pp. 44-46.

${ }^{44}$ Kistler, War Elephants, p. 36; Fasse, Im Zeichen des „Tankdrachen“, pp. 130-46.
} 
In anti-tank warfare, there were other solutions developed by the Germans, such as the Flachmine 17, essentially a wooden box containing a main charge with spring percussion detonators. This form of defence against tanks had arguably a parallel in the antique. In the summer of 312 BC at the Battle of Gaza, Ptolemy came up with the idea of fixing iron hooks to chains (or, caltrops) in order to injure the feet of the elephant. Moreover, he directed his light troops not to kill the elephants but rather the mahouts. The method of injuring the feet of the elephants had the effect of creating chaos during the attack by Demetrius, whose cavalry was also affected by the panic which ensued. The impact on Demetrius battle-plan was immense, to the extent that he lost the battle, with his troops fleeing the field in blind panic. A further parallel can be seen in the tactic of spear-throwers aiming at the eyes of the elephants since German infantry shot at the vision slits of British and French tanks. A further parallel is in the use of fire: flamethrowers could be used in close combat against tanks, while in ancient warfare, in addition to the flaming arrows fired at elephants, there was the famous 'flaming pigs' tactic, pigs coated with pitch, which was ignited, with the squealing animals then set among the elephants, who panicked and stampeded. ${ }^{45}$

What emerges here is offensive means being met with defensive measures, then improved offensive tactics, with the development over time of a spiral of measures and counter-measures, referred to by Fuller as the 'constant tactical factor' ${ }^{46}$ For war elephants, three responses to the counter-measures were developed to protect them better. In order to help the animals cope with the noises of battle, elephants were trained to get used to shouts and the deliberate use of noise by the enemy. Second, direct and indirect protection were

\footnotetext{
${ }^{45}$ Kistler, War Elephants, pp. 58-61, 90-133; for an order recommending that German troops aim their fire at British tanks' vision slits, Bayerisches Hauptstaatsarchiv, Kriegsarchiv, München, 11. Infanterie-Division, Bd. 96, Chef des Generalstab des Feldheeres, Nr. II 73004 op. vom 21.12.1917 betr. Bericht der 119. InfanterieDivision über Tankbekämpfung. For further details on the German anti-tank mine and ditches, see the pieces published in the journal of the US Army Corps of Engineers: 'German Mine for Wrecking Tanks', and 'AntiTank Defenses', Professional Memoirs, 11 (Jan/Dec 1919), pp. 305-7, 422-29; and, Fasse, Im Zeichen des „Tankdrachen“, pp. 576-78, 625-26, 652-53.

${ }^{46}$ J.F.C. Fuller, 'The Influence of the Constant Tactical Factor on the Development of War', Journal of the Royal Artillery, 57 (July 1930), pp. 215-34.
} 
improved: to combat swords directed against their legs, the solution was to place infantry around them to guard against such attacks, in addition to the metal bands wrapped around their legs for more direct protection. Further armour was hung over the elephant's body, while additional protective armour was produced for the head and trunk. Third, the hitting power available to the elephant as a 'weapons system' was improved by increasing the number of spear-throwers or archers on the elephant's back (a maximum of three on Indian elephants, four if housed in a tower), as well as attaching a sword or spikes to the trunk of the beast, which it could then swing against attacking infantry. ${ }^{47}$

These forms of protection had parallels in the First World War and in subsequent conflicts. It was discovered quickly that tanks were much more effective if employed in close cooperation with infantry, so that the enemy of the tanks - either enemy infantry or artillery, which aimed their fire at tanks - could either be destroyed or suppressed. In the last year of the war, the first serious attempts were made to create 'armoured infantry', infantry which travelled in Mark $\mathrm{V}^{*}$ tanks, the first 'panzer-grenadiers' in military history. Memoranda written by staff officers of the British Tank Corps demonstrate that the importance of infantry accompanying tanks during an attack was recognized very early on. When in late 1917 the first warning was made about the threat of a German tank unit appearing on the Western Front, it was suggested that one element of a successful anti-tank defence would be to separate the infantry from the attacking tanks. ${ }^{48}$

Another phenomenon where one can identify parallels between war elephants and tanks is in the capture of numbers of each respective 'weapons system'. There are numerous examples of captured elephants being used in battles against their former owners. Kublai Khan, the 5th Mongolian Emperor, and First Emperor of the Yuan Dynasty in China, reputedly captured around 1272 AD more than two-hundred elephants from the King of Mien

\footnotetext{
${ }^{47}$ Kistler, War Elephants, pp. 11-12, 21-22, 183, 213-14, 216, 222; Head, Armies, pp. 182-86.

48 TMARL, Fuller Papers, Private Journal of Lt. Colonel J.F.C. Fuller, A5, SECRET, HQ, Tank Corps to General Staff, GHQ, Anti-Tank Defence, [sgd.] J.F.C. Fuller, 30 December 1917, pp. 2, 8.
} 
and Bangalla. However, on occasions, those armies which had captured elephants were unaware of the proper principles for their employment. ${ }^{49}$ In the First World War, German Beutepanzer played a relatively limited role on the Western Front due to their modest numbers. Still, by November 1918, the Imperial German Army tank force consisted of 170 captured British Mark IV tanks, two Medium A 'Whippet' tanks, at least one French tank, 20 A7V machines, and a couple of prototypes. The very limited experience gained did lay the basis in the 1930s, however, for the formation which was to become the Panzertruppe. ${ }^{50}$

It is harder to compare the operational use of elephants and tanks than their tactical functions since it is difficult to identify a level of war between tactics and strategy in the ancient world, or an operational role for tanks in the Great War. Nonetheless, the capacity to conduct extended marches, as well as the relative strength of both weapons in relation to other arms, are subjects worthy of closer examination. According to one source, before Hannibal began his march across the Alps, his army was composed of 100,000 men, 12,000 horses, 58 war elephants, as well as thousands of animals carrying equipment and supplies. When he commenced his march, he left some elephants behind with his brother Hasdrubal as part of a garrison. ${ }^{51}$ Although there are many examples of larger formations of elephants, there was a similar disproportionality between infantry, artillery and the tank forces in both world wars, comparable in very broad terms with the elephant forces of antiquity. During the First World War, the strength of the tank arm in relation to combatant strength never rose above $1.51 \%$ in the British Army in France. ${ }^{52}$

Elephants' march rates compared quite favourably with those of interwar tanks and, without doubt, exceeded those of First World War tanks. According to Spenser Wilkinson, during Hannibal's crossing of the Alps his average march rate up the valley of the Rhone was

\footnotetext{
${ }^{49}$ Kistler, War Elephants, pp. 39, 59, 68-69; Ranking, Historical researches, p. 55.

${ }^{50}$ Pöhlmann, Mechanisierung des Krieges, p. 99; and, Fred Koch, Beutepanzer im Ersten Weltkrieg: britische, französische und russische Kampf- und Panzerwagen im deutschen Heer (Wölfersheim-Berstadt, 1994).

${ }^{51}$ Dennis Proctor, Hannibal's March in History (Oxford, 1971), pp. 25, 28, 35.

${ }^{52}$ War Office, Statistics of the Military Effort of the British Empire, pp. 65-66.
} 
rather less than nine miles a day, while his opponent Scipio was unlikey to have managed more than four or five miles a day. In other words, Hannibal was not slowed down by his elephants. ${ }^{53}$ This is noteworthy, given the logistic challenges which an elephant force imposed upon a commander: an elephant required between 70-150 litres of water and 150$300 \mathrm{~kg}$ of feed daily. It has been calculated that a fully 'crewed' elephant (assuming a 'crew' of five) was equivalent to the cost of supplying twelve cavalrymen and their horses. ${ }^{54}$

When it comes to logistics, which relates closely to the operational capability of both elephants and tanks, both weapons systems were able to demonstrate impressive capabilities. A British officer, serving in India in the mid-nineteenth century, recalled in a memoir how much elephants could carry, a capacity which will have not been significantly different in antiquity. They were able to carry six men, complete with their arms, ammunition and bedding, as well as rations. He also noted that they were able to lift heavy guns, while if the pioneers cut the roots of trees, the elephants would finish the job of felling them. ${ }^{55}$ The capacity of tanks to increase logistic capability on the Western Front was demonstrated in the preparations for and during the Battle of Cambrai in November 1917. There were 54 supply tanks used in the battle, but also 110 'sleds' were built to be pulled behind the supply and fighting tanks, thus increasing the overall resupply capacity. ${ }^{56}$

Further parallels can be identified in relation to the pre-battle deployments of both elephants and tanks. In the case of elephants, they were often placed in a line in the centre, together with light infantry, to break up the enemy infantry; and they could be deployed on the flanks to frighten and disrupt enemy cavalry attacks. British tank attacks in the First World War also involved close cooperation with infantry, which followed the tanks to support them in attacks on German defensive positions; an advance guard of tanks would

\footnotetext{
${ }^{53}$ Spenser Wilkinson, Hannibal's March through the Alps (Oxford, 1911), pp. 16-17.

${ }^{54}$ Holger Müller, 'Tiere als Kostenfaktor in antiken Kriegen', and Sebastian Buziak, 'Kriegselefanten Giganten an der Front', in Pöppinghege (ed.), Tiere im Krieg, pp. 15-31, here 27-30, and pp. 33-46, here 39.

${ }^{55}$ Sidney Cotton, Nine Years on the North-West Frontier of India, from 1854 to 1863 (London, 1868), pp. 90-92.

${ }^{56}$ Harris, Men, Ideas and Tanks, pp. 107-33.
} 
often lead the assault, followed by one or more waves. The similarity lies in the fact that poor deployments made before the battle, which did not take account of enemy defences or plans, could not usually be corrected once the attack had commenced. ${ }^{57}$ While these deployments might be dismissed as mere tactics, there were obvious 'operational dimensions' to the role of both weapons in some battles. At the Battle of Zama (October 202 BC), Scipio Africanus eschewed the typical checkerboard deployment for his cohorts, laying out rows of cohorts with corridors between them through which the elephants would run. Through a variety of strategems, he induced them to charge through the corridors, enbling his forces to pelt the elephants with spears and arrows from two sides; the ensuing chaos caused them to charge off the battlefield. ${ }^{58}$ By January 1918, the Headquarters of the British Army Tank Corps had begun to differentiate between tactical objectives, strategical localities (e.g., bridges) and administrative centres (e.g. enemy headquarters) for tank attacks. ${ }^{59}$ The emerging operational possibilities of tank formations were further identified in Fuller's famous memorandum usually referred to as 'Plan 1919'; it could also be seen for the first time in embryonic form at the Battle of Amiens (August 1918). ${ }^{60}$

Moreover, it can be noted that both weapons were clearly important enough that their surrender was a demand which was often made as part of peace negotiations, something which suggests that their significance extended beyond even 'operational functions' right up to the level of strategy. In the wake of Scipio Africanus' victory at the Battle of Zama in 202 BC, the Romans imposed peace terms, which were to be administered by Scipio, that Carthage pay an indemnity of 10,000 silver talents in fifty annual installments, Massinissa

\footnotetext{
${ }^{57}$ Head, Armies, pp. 25-26; TMARL, Fuller Papers, Private Journal of Lt. Colonel J.F.C. Fuller, A20, Infantry and Tank Co-operation and Training, 27 January 1918 (issued by General Staff as S.S. 204 in March 1918). ${ }^{58}$ Kistler, War Elephants, pp. 130-34.

${ }^{59}$ TMARL, Fuller Papers, Private Journal of Lt. Colonel J.FC. Fuller, A5, SECRET, Tank Corps HQ to GHQ, Notes on visit of Major B. Paget to Tank Corps HQ on 13.1.18, 15 January 1918.

${ }^{60}$ Fuller, Tanks in the Great War, pp. 230-35. The original version of 'Plan 1919' was titled 'The Tactics of the Attack as Affected by the Speed and Circuit of the Medium D Tank', and can be found at TMARL, Fuller Papers, Private Journal of Lt. Colonel J.F.C. Fuller, B62, dated 24 May 1918. The finalised, typed version, including a detailed appendix, can be found at LHCMA, Fuller Papers, Tank Corps I/1/50/1-12, with no change to the original title.
} 
(the King of Numidia) was to have his ancestors' land returned, the Carthaginians were to carry out no attacks outside their territory without the agreement of Rome, and the hand-over of all war ships (with the exception of ten triremes) and war elephants was ordered. ${ }^{61}$ Despite the disputed combat value of the elephants in Hannibal's possession, they were important enough that their surrender was at the very least understood as a symbolic measure which would help preserve the peace. This aspect of the settlement after Zama can be compared with some of the conditions of the Treaty of Versailles. As well as the 'war guilt' clauses, according to Articles 171 and 198 of the Treaty, the new German Republican armed forces were forbidden from possessing armoured cars, tanks or aircraft; and, during the course of $1919 / 20$, the 59 tanks still remaining in the inventory were broken up for scrap. ${ }^{62}$

\section{The Two 'Weapons Systems' as Symbols of Power}

A comparison based on our starting point - namely, that the art of war in the antique and early twentieth century possess certain commonalities - must be developed beyond tactics and field strategy. Once again, there is a further area in which some parallels can be identified: the respective roles of the two weapons as symbols of power. This symbolism can not only be seen in victory parades and other events staged by rulers, but also through the way in which both weapons systems were portrayed via cultural artefacts for wide distribution among the people, celebrated, and as a result became part of collective memory and societal identity. Indeed, as a symbol of power, both weapons systems found occasionally a use as an instrument for the carrying out of public executions.

In many ways, war elephants anticipated the 'modernity' of the tank as a means by which military power could be communicated in both a real and symbolic fashion. In states

\footnotetext{
${ }^{61}$ Fuller, Decisive Battles, Vol. 1, p. 144; H.H. Scullard, 'The Carthaginians in Spain', in A.E. Astin \& F.W. Walbank (eds.), The Cambridge Ancient History, Volume VIII: Rome and the Mediterranean to 113 B.C. (Cambridge, 2nd edn, 1989), pp. 17-43, here, 62-65.

62 Treaty of Peace between the Allied and Associated Powers and Germany and Protocol. Signed at Versailles, June 28th, 1919 (Ottawa, 1919), pp. 66, 74; Pöhlmann, Mechanisierung des Krieges, pp. 117, 131-32, 139-47.
} 
which possessed organized armed forces, especially in the Roman Republic, parades of soldiers fulfilled different functions. From the most simple perspective, they could demonstrate state power in public in two ways: on the one hand, through the display of the military power of the ruler and/or the ruling elite, it could be demonstrated to anyone who might have entertained thoughts of overthrowing state authority that it would be inadvisable to do so; on the other, a feeling of security could be communicated to the citizens of Rome. A further function of such public parades was to celebrate victories, so that the citizens could develop a sense of pride in their soldiers, while the victorious generals and their commander could bask in the glory of victory. ${ }^{63}$

The significance of war elephants and tanks in public appearances was that they broke the usual order of traditional parades. Elephants smelt differently and were, of course, capable of deficating during such events, but at the same time were impressive due to their sheer size; they achieved a new level of symbolism because they communicated the conquest of nature by man; and, they could be decorated and contribute to the dramatic colour of such events. During Alexander's return from India to Babylon in $325 \mathrm{BC}$, he placed himself within a large group of elephants. They presented the ultimate symbol of military power. They fascinated the inhabitants of cities, many of whom had never seen an elephant before. In the first half of the twentieth century tanks fulfilled a similar role because they moved parades away from the era of cavalry and horse-drawn transport: they communicated the mastery of new technology, the inventiveness of an industrial nation and the capacity of its industry. Like elephants, they removed the previous pomp and grandeur of parades as they threw up dust, making a huge noise as they drove past. They symbolized total war because the efforts of factory workers as much as engineers had led to the creation of each individual tank. Tanks appeared in numerous victory parades after the Great War, such as in Paris on 14 July

\footnotetext{
${ }^{63}$ E. Künzl, Der römische Triumph (Munich, 1988); Mary Beard, The Roman Triumph (Cambridge, Mass., \& London, 2007); H.S. Versnel, Triumphus: An Enquiry into the Origin, Development and Meaning of the Roman Triumph (Leiden, 1970).
} 
1919, or in London on 19 July 1919, unseating the cavalry from its earlier place of honour in pre-1914 celebrations of military power. ${ }^{64}$

It is worth noting that occasionally in history, the ancient world could seemingly meet with modernity where military parades were concerned. In May 1935 an order was placed by Iran for Czechoslovak TNH tanks, the forerunner of the Panzerkampfwagen 38(t), a tank seized by the Germans when they occupied Czechoslovakia in March 1939. Fifty of these machines had been delivered by May 1937. Yet, apparently, they were mainly used for show during the annual military review. While they were concentrated in an Imperial Mechanized Brigade, their training was poor, with the crews frequently stalling the machines. The real intention was to have them serve as a 'palace guard' for the Pahlavi dynasty in Tehran. The lack of interest in their actual military value would suggest that the reason for their purchase was to impress the population as to the might of the rulers, hinting at a throwback to the role of Sassanid war elephants as a means of impressing the dynasty's subjects. ${ }^{65}$

As part of the relationship between 'weapons system' and military power, the communication of military and state values was not merely a function of parades and other forms of public celebration. Cultural artefacts played a role in the diverse forms of the symbolism of power, with the respective populations owning specific objects. ${ }^{66}$ The weapons were thus immortalised and celebrated through various artefacts. In the case of war elephants, there were numerous examples of images appearing. A coin minted in $280 \mathrm{BC}$ in Pergamum shows an Indian elephant of Seleucus I of Syria. A painted plate from Capena in the style of the Etruscans around the third century BC shows an Indian elephant, its mahout, and the howdah (castle) on its back, 'crewed' by two Macedonian warriors. Military decorations

\footnotetext{
${ }^{64}$ H.H. Scullard, The Elephant in the Greek and Roman World (Cambridge, 1974), pp. 72-73; Alaric Searle, Armoured Warfare: A Military, Political and Global History (London, 2017), pp. 196-97.

${ }^{65}$ Steven J. Zaloga, Panzer 38(t) (Oxford, 2014), pp. 5-6; Charles, 'Sassanian Elephant Corps', pp. 337-41.

${ }^{66}$ On this, see Jan Assmann, 'Communicative and Cultural Memory', in Astrid Erll \& Ansgar Nünning (eds.), Cultural Memory Studies: An International and Interdisciplinary Handbook (Berlin/New York, 2008), pp. 10918, and idem, Das kulturelle Gedächtnis: Schrift, Erinnerung und politische Identität in frühen Hochkulturen (Munich, 1992).
} 
likewise incorporated images of elephants. One also finds pictures of war elephants in Roman mosaics on the floors of buildings. ${ }^{67}$ Most famously, to commemorate his victory over Porus at the Battle of Hydaspes (326 BC), Alexander had a coin minted with his head on one side and an image of an elephant on the other. ${ }^{68}$

The representation of British tanks during and immediately after the First World War shows a similar saturation of public perceptions and national emotions through artefacts. Just like the form of an elephant, the lozenge shape of British tanks in the First World War was immediately recognisable, while at the same time infused with various connotations, such as the nation's inventiveness in wartime. ${ }^{69}$ For these two reasons, tanks appeared in advertisements for soap and cigarettes. ${ }^{70}$ In Britain, a public campaign on the home-front to increase the sale of war bonds was hugely successful due to the mock battles staged by battlescarred tanks, while mock-up tanks appeared in towns which the tank war bond 'road show' was not able to visit. ${ }^{71}$ Needless to say, tanks were photographed frquently during the war, with the images published in newsapers and books. The enthusiasm which tanks could unleash can be seen in some of the newspaper reporting shortly after the opening of the Battle of Cambrai. The title page of the Daily Graphic on 29 November 1917 shows four large photographs of tanks moving across the battlefield and in a destroyed village, indicating the insatiable appetite of the readers for any visual material related to tanks. ${ }^{72}$

One of the differences between war elephants and tanks within the context of the comparison is that, during the First World War, the opportunities for the distribution of imgaes of the tank were much greater. Still, the extended period of time in which war

\footnotetext{
${ }^{67}$ De Beer, Hannibal, pp. 101-7.

68 These medallions have been the subject of much debate for many years: Frank L. Holt, Alexander the Great and the Mystery of the Elephant Medallions (Berkeley, CA, 2005); and, D. Pandey, 'The Hydaspese-battle Commemorative Medal of Alexander the Great - A Fresh Approach', Journal of the Numismatic Society of India, 33 (1971), pp. 1-7.

${ }^{69}$ Searle, Armoured Warfare, pp. 193-96.

${ }^{70}$ See, for example, the advert for "Wright's Coal Tar Soap", Army and Navy Gazette, 58 (26 May 1917), p. iv, in the advertising section of the newspaper.

${ }^{71}$ Patrick Wright, Tank: The Progress of a Monstrous War Machine (London, 2000), pp. 81-100.

72 'The "Tanks" in their Greatest Victory', Daily Graphic, 29 November 1917, p. 1.
} 
elephants played a role on the battlefield suggests that within the broad parameters of the comparison the point is, nonetheless, a valid one. The argument here is the variation in the means of communication of the image: the image of the weapon appeared on military uniforms, in objects for use in a citizen's house and on everyday items such as coins, or in advertising. The elevation of the weapon system to the status of a cultural artefact highlights the psychological impact of the 'weapons system' within societies in two different historical epochs. The inclusion of the weapon as part of the cultural memory of ancient and modern societies suggests that the two 'weapons systems' served a much broader symbolic function than that generated by the more common hand-held weapons. ${ }^{73}$

The final point of comparison which can be made concerns the employment of both weapons systems as a means of execution through which potential criminals or those wishing to challenge authority were to be dissuaded through the gruesome nature of the public 'performance' of the sentence. Some illustrations show the use of elephants for public execution, with one of the feet of the animal placed on the chest or head of the convicted individual. The death sentence is then carried out by the weight of the elephant crushing the miscreant. ${ }^{74}$ Although very few documented examples are known of the use of tanks as a means of execution, one Uzbek warlord in Afghanistan in the late 1990s, a certain Abdul Rashid Dostum, apparently tied those who had fallen foul of him to tracks of a captured Russian tank, in order to crush them in front of his followers in a demonstration of authority in a fashion quite similar to the employment of an elephant as an executioner. ${ }^{75}$

\footnotetext{
${ }^{73}$ Evert, Die Eisenbraut, esp. pp. 137-42, 306. See also the critique of her interpretation of the symbolism of tanks in the interwar period as relating to nationalism in Pöhlmann, Mechanisierung des Krieges, p. 293 , n. 610. ${ }^{74}$ Kistler, War Elephants, pp. 15, 182.

${ }^{75}$ On Dostum's reputation as a man who employed tanks as a means of execution, see Ahmed Rashid, Taliban: The Power of Militant Islam in Afghanistan and Beyond (London 2010), p. 76. It should be mentioned, however, that some commentators dispute this grisly reputation, and see him as an Uzbek patriot, mainly concerned with welfare of his people. The story of tanks as a means of execution has been ridiculed as a journalistic exaggeration. Brian Glyn Williams, 'Dostum the Taliban Killer': Afghanistan's Pro-American Warlord, in: The World Post, 12 April 2013, at http://www.huffingtonpost.com/brian-glyn-williams/dostum-the-talibankiller_1_b_4385095.html; accessed 30 March 2017.
} 


\section{Analysis}

Where then does this comparison of war elephants and tanks leave us in the final analysis? At the outset, three central issues were raised surrounding the apparent similarities between the employment of war elephants and early tanks. First, the question was posed as to why MajorGeneral J.F.C. Fuller, the leading theorist of armoured warfare in the 1920s and early 1930s, never drew a comparison between war elephants and tanks in his writings, despite his belief that the basic principles of strategy had not changed since antiquity. Second, on the basis of the parallels between elephant and tank warfare, can any conclusions be drawn about principles of war or battle which can be identified in both ancient and modern warfare? Third, and building here upon the second question, are there any broader conclusions which can be drawn from the comparison about the nature of strategy in general? To answer these questions, the issues around historiography will be tackled before considering commonalities between war elephants in ancient and early tanks in modern warfare.

\section{(i) Historiographical Context}

It is important to begin with a central conundrum surrounding the comparison, namely, the failure of J.F.C. Fuller to draw a comparison between war elephants and tanks, despite his strong interest in the precursors of the new war machine. This is all the more important given his argument that the campaigns of Alexander could teach the contemporary soldier much, 'because war is an art which, whatever be the period in question, is based on the same principles, and only their application varies from date to date.' ${ }^{76}$ While his book on Alexander, and his final work, a study of the generalship of Julius Caesar, were largely concerned with 'grand strategy', the discrepancy is worth noting. ${ }^{77}$ For in his description of

\footnotetext{
${ }^{76}$ Fuller, Alexander the Great, pp. 306-14, quote, 306.

${ }^{77}$ J.F.C. Fuller, Julius Caesar: Man, Soldier, and Tyrant (New Brunswick, NJ, 1965). In fact, in a letter to his American publisher, Fuller noted that he was essentially interested in drawing a comparison between Caesar and Adolf Hitler. LHCMA, Major-General J.F.C. Fuller Papers, IV/6/36/2, Fuller to Sloane, 2 November 1964.
} 
the precursors of the tank in his book Tanks in the Great War 1914-1918 (1920) Fuller provided a detailed description of human inventions; his main point of focus was medieval battle carts, as well as the invention of the battle tractor in 1888. The omission of elephants is surprising when one reads that he identified four problems which had repeated themselves over 4,000 years of history: 1.) how one hits a soldier from a distance; 2.) how one can approach enemy lines; 3) how one can hit an opponent over a short distance; and, 4.) how one can protect oneself during a battle. ${ }^{78}$ This analysis would seem to have provided a good basis for a comparison of war elephants and tanks.

Nonetheless, he did on one occasion come closer to the comparison in Armament and History, writing directly after the Second World War. In this work, he described the war elephant as the 'shock arm' in the era of Alexander the Great, even considering their employment as 'the greatest innovation of all'. But one of the reasons why he refrained from taking the comparison any further was that Alexander, whose campaigns he described as 'blitzkriegs', generally built his success around his cavalry and never employed pachyderms in war. Fuller's reading convinced him that elephants were generally unreliable, but at the same time he remarked that 'how elephants were combined with infantry and cavalry is not known' ${ }^{79}$ Certainly, then, lack of historical knowledge must be put down as one explanation for his failure to draw the comparison. But there were three other significant reasons.

In the early period of the development of the tank, when Fuller was General Staff Officer 1st Grade on the staff of the British Army Tank Corps, soldiers thought very precisely in terms of the nineteenth-century roles of infantry, cavalry, artillery and engineers. This emerges from wartime Tank Corps memoranda authored by Fuller in which he considered, for instance, the Mark V tank as offering 'almost an exact parallel to the use of heavy cavalry

\footnotetext{
${ }^{78}$ Fuller, Tanks in the Great War 1914-1918, pp. 1-17. The Scottish 'war cart', which is mentioned by Fuller, as well as the 'caterpillar tractor' of 1888, are also the subject of discussion in Clough Williams-Ellis \& A. Williams-Ellis, The Tank Corps (London, 1919), pp. 6-7.

79 J.F.C. Fuller, Armament and History: A Study of the Influence of Armament on History from the Dawn of Classical Warfare to the Second World War (London, 1946), pp. 43-44.
} 
in the Napoleonic era', in essence, as a weapon suited to the counter-offensive. ${ }^{80}$ Fuller's theory of tank warfare was, furthermore, based around the idea that machine-power was more efficient than muscle power. Such a view naturally dove-tailed well with what has become the dominant narrative - that the invention of the tank represented a revolution in warfare. ${ }^{81}$ Furthermore, other sources written during the war identify the precursors of the tank as the cavalry armies of Ghengis Khan, the chariots of antiquity and medieval knights, who - like tanks - carried armoured protection. ${ }^{82}$

To add to these reasons, it was the case that in Fuller's lifetime military history had not advanced to a point where concepts such as 'the revolution in military affairs', military effectiveness, weapons systems or comparative and cultural-historical approaches had come into general usage. While military history had started to consider the societies from which armies sprang, and was open to making use of ancient history to discuss contentious points, the main motive remained to extract principles from history which might improve battlefield performance in the future. Since comparisons of war elephants and tanks were seen as a product of the 'popular imagination', they were often dismissed as 'misleading' and as a notion which was not worth taking seriously. ${ }^{83}$

But the most significant reason for Fuller's unwillingness to draw a comparion between war elephants and tanks probably lay in the internal army politics surrounding the debate over mechanization in the 1920s and 1930s. ${ }^{84}$ Those who supported the argument that

\footnotetext{
80 TMARL, Fuller Papers, Private Journal of Lt. Colonel J.F.C. Fuller, B75, SECRET. Notes on the Use of the Mark V and Whippet Tanks in the Counter-Offensive Battle, n.d. [early 1918].

${ }^{81}$ Fuller, Tanks in the Great War, p. 229.

82 'Tanks', Army and Navy Gazette, 59 (14 September 1918), pp. 585-86.

${ }^{83}$ In this context, the headline above two photographs of British Mark IV machines taken around the time of the Cambrai battle in 1917 is interesting. 'H.M. Landships Outdo Hannibal's Elephants', The War Illustrated, 15 December 1917, p. 343. It is also worth noting that one of the leading British historians of antiquity in the interwar period stated in the Lees-Knowles Lectures of 1929-30, 'To compare elephants with tanks is, in my opinion, quite misleading.' W.W. Tarn, Hellenistic Military and Naval Developments (Cambridge, 1930), p. 96. ${ }^{84}$ For the history of mechanization in the British Army in this period, see: Harris, Men, Ideas and Tanks, pp. 195-314; Robert H. Larson, The British Army and the Theory of Armored Warfare, 1918-1940 (London \& Toronto, 1984); Harold Winton, To Change an Army: General Sir John Burnett-Stuart and British Armoured Doctrine, 1927-1938 (London, 1988).
} 
the army required mechanization tended to argue from a very linear interpretation of history. Progressive officers, such as George M. Lindsay, saw animals in war as representing 'congestion and immobility' through their role in pulling chariots and supply wagons. Writing in 1926 in his capacity as Inspector of the Royal Tank Corps, Lindsay argued that animals pulling vehicles were extremely vulnerable, so that the emergence of cavalry represented a major new epoch in the development of warfare. He considered that the mounted archer armies of the Parthians were the best example of the combination of firepower and mobility; subsequently, even more successful were the mounted archers of the Mongols in the eleventh and twelfth centuries. But his main argument was that the horse had become increasingly vulnerable through the course of history, so ultimately it would need to be phased out in favour of armoured fighting vehicles. ${ }^{85}$

This said, in the 'history of the tank idea', Lindsay was also willing to acknowledge in 1926 that among the precursors of that idea (the central elements of which were firepower, mobility, protection and morale), in addition to the linking of shields by the Assyrians, Egyptian and Romans, Cyrus's wagon towers and Chinese battle wagons, one could also identify the elephants of Darius, Porus, the Romans and the Carthaginians. ${ }^{86}$ One officer went even further than Lindsay, arguing in the same year that tank and anti-tank tactics were 'almost identical' when compared to the employment of elephants in battle. ${ }^{87}$ The problem in the identification of the war elephant as a precursor to the tank for the advocates of mechanization was that this argument could be turned against them by those who were afraid of the implications of military reform. In his address to officers of the British Army's

\footnotetext{
${ }^{85}$ LHCMA, Liddell Hart Papers, LH 15/12/5, SECRET AND PERSONAL. Reply to the Questionnaire on the Cavalry requirements of the Army by Col. G.M. Lindsay, Inspector of the Royal Tank Corps, 25 September 1926.

86 TMARL, Major-General George M. Lindsay Papers, Tank Corps box 2, Precis of Lecture on Tanks and their Co-operation with other Arms by Colonel-on-the-Staff G.M. Lindsay, CMG, DSO, Inspector, Royal Tank Corps, 18 February 1926.

${ }^{87}$ Capt. \& Brevet-Major H.G. Eady, Royal Engineers, 'The Tank. "Full Circle Goes the Wheel."', Journal of the Royal United Service Institution, 71 (1926), pp. 81-93.
} 
experimental mechanized force in September 1927, the Chief of the Imperial General Staff (CIGS), General George Milne, was quick to state that the tank 'is not in the slightest degree of itself a new idea'. It was merely 'a new method of carrying out an old idea' - and that idea had, of course, already been demonstrated by the elephant 'in the days of Hannibal' ${ }^{88}$

What terrified Milne, who occupied the post of Chief of the Imperial General Staff from 1926-1933, was that he equated the arguments of the mechanical warfare enthusiasts with the destruction of military tradition. Most revealing in this respect are some of the marginal comments written by Milne on a report prepared by Lindsay in 1926 on the future of the Royal Tank Corps. While the CIGS was prepared to accept that Lindsay was arguing along the right lines, next to the statement that there was a need to break away from the regimental system and create uniformity in training, Milne wrote: 'No I can't agree with this. You want to abolish all tradition'. ${ }^{89}$ Thus, it is the historical context of the battle over mechanization in the British Amy in the interwar period which provides the central background to Fuller's approach to interpreting the role of the war elephant in ancient history. It seems more than likely that he would have been unwilling to consider the elephant as a precursor of the tank because this was a rhetorical device used by the critics of mechanization to call into question the claim that the tank was a radically new weapon which had overthrown conventional notions of warfare and, hence, required new methods and tactics.

It should not be forgotten, however, that there is a further dimension to the historiography surrounding this comparison, namely, earlier historical writing on ancient warfare. If one takes a historian such as Johann Gustav Droysen, accomplished scholar though he was, his descriptions of the employment of elephants in Alexander's campaigns served the creation of a vibrant and dramatic narrative, intended to transport the reader into

\footnotetext{
${ }^{88}$ LHCMA, Field-Marshal George F. Milne Papers, box 3, Address to the officers of the Mechanized Force by the C.I.G.S. at Tidworth, 8 September 1927, typescript, p. 3.

89 TMARL, Lindsay Papers, Tank Corps box 1, T13, SECRET. Col. G.M. Lindsay, B.M. 796. Suggestions regarding the best means of rendering the Royal Tank Corps in particular and the army in general more suited to the probable requirements of future warfare, 15 May 1926.
} 
the drama of the events. ${ }^{90}$ In addition to the criticism which was levelled at his errors in the use of source material, and the suspicion that he sympathised with the winners in history, there were obvious ulterior political intentions behind his work. ${ }^{91} \mathrm{~A}$ very different approach to writing on the antique in Germany came with the publication of Hans Delbrück's first volume of his 'History of the Art of War'. He lurched, though, in the opposite direction, casting suspicion almost on principle over every type of source, often dismissing the descriptions of classical writers with more than a touch of dogmatism. ${ }^{92}$ Not until the advances in historical analysis which came after 1945 was it possible for a more accurate and balanced picture of the role of war elephants to emerge.

\section{(ii) Transepochal Comparative Assessment}

These are important points of clarification as, otherwise, it might be less credible to return to Fuller's claim that the art of war was based upon the same principles in the antique as it was in the twentieth century. But how strong is the evidence for this? In this comparison, what has been identified is much less principles for the conduct of war (such as surprise, mobility, or economy of force) as Fuller understood them. What has been discovered, in contrast, are general phenomena which can be identified as recurring in military history since antiquity. Rather than 'principles', these are military processes or phenomena which evolve over time, or occur within certain phases of military-technical development.

The first observation to emerge from the comparison is the obvious similarity in the continual struggle for the tactical advantage during combat. In both cases, comparable

\footnotetext{
90 Johann Gustav Droysen, Geschichte Alexander des Großens (Hamburg, n.d. [1833]), esp. pp. 407-14.

${ }^{91}$ Wilfried Nippel, Johann Gustav Droysen. Ein Leben zwischen Wissenschaft und Politik (Munich, 2008), pp. 25-33, for a useful discussion of the contemporary criticism of Geschichte Alexander des Großens, published when Droysen was just twenty-five.

${ }^{92}$ Hans Delbrück, Geschichte der Kriegskunst. Band 1: Das Altertum [first published, 1920] (Berlin, 2000), pp. 234, 246, 263, 279, 344, 438, 447, 679. In some ways, Delbrück was positioned at the other end of the scale to Droysen, coming into conflict with the Prussian General Staff over his approach to the writing of military history. See here, Sven Lange, Hans Delbrück und der $>$ Strategiestreit $<$. Kriegführung und Kriegsgeschichte in der Kontroverse 1879-1914 (Freiburg i.Br., 1995).
} 
measures were undertaken to reduce the superiority of war elephants and tanks. During the initial attack, passive defensive measures were employed - caltrops were used to stop elephants, anti-tank ditches and mines to halt tanks. An attack could also be disrupted by more active measures: loud noises or fire could be used to frighten elephants, whereas to break up a tank attack the enemy infantry needed to be separated from their tanks. Defenders aimed to strike with hand-held weapons or projectiles against the vulnerable points of both weapons systems. In the case of war elephants, these points were the tendons at the backs of their legs, the eyes, the underbelly, whereas for tanks it was the vision slits, the weak armour at the sides and rear, and the tracks. ${ }^{93}$

The second of point of similarity, and central to this comparison, is the basic concept of combined-arms cooperation. War elephants, like tanks, were always part of a larger formation, which often consisted of infantry, cavalry, archers and, at times, catapults and chariots. While both war elephants and tanks created the notion among civilians and military officers alike of a 'wonder weapon', ${ }^{94}$ success was dependent in most cases upon the practicability of the overall plan, the quality of the respective units and combined-arms cooperation. ${ }^{95}$ When faced by an intelligent commander, war elephants could fail when outmanoeuvred by enemy cavalry and infantry, or if they were poorly positioned in relation to the opposing forces. In the first half of the twentieth century, the situation was similar in the

\footnotetext{
${ }^{93}$ Caltrops and other means of anti-elephant warfare are referred to by Vegetius. See Military Institutions of Vegetius, in five books, translated from the original Latin, with a Preface and Notes by Lieutenant John Clarke (London, 1767), pp. 154-57. By mid-1918, German anti-tank instructions had become very detailed, and indicated they had identified the weak spots of British and French tanks, including the vision slits. See LHCMA, Fuller Papers, Tank Corps I/1/128, translation of a German document, Seventeenth Army Headquarters, AntiTank Defence, 21.9.1918.

${ }^{94}$ Both Ernest Swinton and Winston Churchill were guilty of this type of wishful thinking, even after the First World War, proclaiming in their war memoirs that much had been possible, but that most reprehensible had been the squandering of surprise through the first attack. E.D. Swinton, Eyewitness (London, 1932), pp. 260-99; W.S. Churchill, The World Crisis 1911-1918 (London, abridged \& rev. edn, 1931), pp. 306-19, esp. 318. Of course, surprise had been a consideration during the early phase of development. Field-Marshal Sir John French reacted positively in June 1915 to Swinton's original idea, noting that there appeared to be 'considerable tactical value in this proposal... particularly if the production of these machines be a surprise to the enemy.' The National Archives of the United Kingdom (hereafter, TNA), WO 158/831, Field-Marshal J.D.P. French (GHQ, France) to the Secretary, War Office, London, 22 June 1915.

${ }^{95}$ For a historical overview of the subject in relation to mechanized war, see Jonathan M. House, Combined Arms Warfare in the Twentieth Century (Lawrence, KS, 2001).
} 
case of tanks. Tank formations could achieve success when they were employed in combination with aircraft, infantry, artillery and specialist troops, such as engineers; but, at the same time, they could do little to rescue a commander who had deployed his various arms poorly before the start of an offensive. Where both elephants and tanks achieved their most spectacular success was often when they were facing less prepared and inadequately equipped opponents.

If we search for common principles to be found in elephant and early tank warfare, further observations can be offered, which go beyond simple rules for employment on the battlefield itself. ${ }^{96} \mathrm{~A}$ third phenomenon which can be identified is that of measure/countermeasure/up-armouring (i.e., Fuller's 'constant tactical factor') which involves increases in firepower in the 'weapons system', followed by counters from the opponent, then improvements in protection. War elephants were first employed with little or no armour: as the threats increased, they were equipped with armour protection, as well as better platforms from which to deliver missiles. In the First World War, the armour on British tanks was discovered to be too thin, so a process of up-armouring began. ${ }^{97}$ Initially, British tanks were divided into 'male' and 'female', the male tanks carrying a 6-pounder gun, while female tanks were armed with machine-guns only. The French Renault FT-17 was armed either with a 37mm cannon, or a machine-gun. But it was the Red Army which first succeeded in developing a version of the tank which mounted both weapons in the turret. ${ }^{98}$

A fourth example of parallels is in the creation of a new breed of 'elite soldiers' to crew the weapons system, but also to combat it, leading in essence to a qualitative leap in training. Mahouts gradually gained a privileged position, allowing them to wear finely

\footnotetext{
${ }^{96}$ See Table 1 below for the presentation of the comparison in tabular form through division into four categories, albeit with the limitation of 'early tank warfare' to the First World War.

${ }^{97}$ For an historical overview of the continual increase in the tank's main armament, 'Appendix I: Growth of Gun Power', and for armour protection, 'Appendix II: The Quest for Greater Protection', in Ogorkiewicz, Tanks, pp. 247-65, 266-81.

${ }_{98}^{9}$ Main \& Searle, 'Tanks in Palestine and Russia, 1916-1921', pp. 186-87.
} 
coloured clothes, a public display of their importance within an army. In the German Panzertruppe in the Second World War, a distinctive black uniform was worn, providing an indication of elite status. ${ }^{99}$ The threat posed by both weapons systems to entire armies lent those tasked with combating the threat, likewise, a certain status. Around 170 BC, the Greeks formed history's first anti-elephant corps, complete with spiked helmets and shields, which were designed to pierce the elephant's hide. In the Second World War, the Japanese Army had little answer to Allied medium tanks since they only possessed light tanks; thus, special tank-hunting teams were trained to attack tanks, often using satchel charges. In urban warfare and close country in Europe, hand-held anti-tank weapons transformed close combat between infantry and tanks, with the Americans using the bazooka, the British the PIAT, and the Germans the lethal Panzerfaust. ${ }^{100}$ Huge doses of courage and self-sacrifice were required in assaulting elephants or tanks, often requiring a willingness to accept almost certain death.

A further aspect which would appear to demonstrate the viability of the comparison is the inherent flexibility of the weapons systems. Elephants showed themselves to be remarkably flexible in their methods of combat: they could employ their tusks against enemy infanty and other elephants, their trunks could pick up opposing soldiers and throw them, they could employ their bulk in charging opponents, as well as trample them to death. Tanks could crush infantry with their tracks; they could also flatten obstacles; and they could turn 360 degrees, by putting one track into forward gear, the other into reverse, thereby collapsing trenches and fox-holes, burying the occupants alive. Projectiles fired from the elephants (both spears and arrows) represented a further means of killing opponents; in the case of tanks, shells fired from the main cannon could be used against opposing tanks, or cannister against infantry; machine-gun fire could decimate enemy infantry caught in the open. Both weapons

\footnotetext{
${ }^{99}$ Kistler, War Elephants, pp. 22-23; Martin Windrow, Tank and AFV Crew Uniforms since 1916 (Cambridge, 1979), pp. 64-79.

${ }^{100}$ Kistler, War Elephants, p. 148; John Weeks, Men against Tanks: A History of Anti-Tank Warfare (London, 1975); and, US War Department, Military Intelligence Division, Japanese Tank and Anti-Tank Warfare, RESTRICTED, Special Series No. 34 (Washington DC, 1945).
} 
systems also possessed considerable 'operational flexibility' in that they could negotiate mountain paths, and be transported or swim across rivers. Each weapons system created combat power far in excess of the numbers of men involved in its operation, recalling the claims of the 'father' of Operations Research, the British mathematician, Frederick Lanchester, creator of the 'square law', who argued that an additional machine-gun added to an aircraft did not double its combat capability, rather it quadrupled it. ${ }^{101}$

To conclude, sixth, what does the comparison reveal about the transepochal nature of strategy and similarities between ancient and modern warfare? Thus far, the analysis has concentrated upon the employment of the two weapons systems in combat and field strategy. But if we can accept that Carl von Clausewitz was the first theorist to unlock the basic DNA of war, then the 'Clausewitzian trinity' of 'government-army-people' becomes quite significant for this comparison. ${ }^{102}$ Principles for the conduct of battle only seem to explain part of the nature of war. Strategy also includes the population supporting any particular war effort. A 'weapons system' intensifies the dynamic link between the people and a campaign (or a war). If a weapons system demonstrates a form of fusion between the crew and the weapon in battle, within the wider context of war the weapons system creates a link between the population and its armed forces. While the commander still retained respect, the appearance of the weapons system 'democratized' warfare by creating a symbol which elevated crew heroism over the figure of the general. ${ }^{103}$

\footnotetext{
${ }^{101}$ For the original theory, see F.W. Lanchester, Aircraft in Warfare: The Dawn of the Fourth Army (London, 1916). Further discussion and details of the range of literature available can be found in: Ronald L. Johnson, Lanchester's Square Law in Theory and Practice, unclassified student research report, School of Advanced Military Studies (Fort Leavenworth, KS, 1990); Richard H. Peterson, 'On the Logarithmic Law of Attrition and its Application to Tank Combat’, Operations Research, 15 (1967), pp. 558-59; James G. Taylor, Lanchester Models of Warfare, 2 vols. (Arlington, VA, 1983); and, T.N. Dupuy, Numbers, Prediction and War: The Use of History to Evaluate and Predict the Outcome of Armed Conflict (Fairfax, VA, 1985).

${ }^{102}$ Carl von Clausewitz, Vom Kriege (Berlin, 5th edn, 1905), Book I, ch. 1, pp. 20-21. For analysis and comment on the 'Clausewitzian trinity', see: Hew Strachan, Clausewitz's "On War": A Biography (London, 2007), pp. 177-82; Beatrice Heuser, Reading Clausewitz (London, 2002), pp. 44-71; and, Edward J. Villacres \& Christopher Bassford, 'Reclaiming the Clausewitzian Trinity', Parameters, 25 (Autumn 1995), pp. 9-19. ${ }^{103}$ Useful perspectives on the question of heroism in war can be found in René Schilling, Kriegshelden: Deutungsmuster heroischer Männlichkeit in Deutschland 1813-1945 (Paderborn, 2002).
} 
Thus, the crew of the weapon leave the traditional heroism of the soldier behind, taking on a new form of 'technicized heroism'. In a sense, individuals become part of the square law; they receive a degree of independence in decision-making; hence, a 'weapons system' as opposed to a weapon democratizes warfare but - paradoxically - creates a new military elite. Yet, successful employment of the weapons system, or its defeat, could elevate the commander to a new heroic level. The dynamic interaction created between the weapons system and the citizen becomes part of the upward spiral of the process of 'up-armouring', creating an additional dynamic to the tactical, battlefield effects of the weapon. It is the trinity of government-army-people who become locked collectively in a struggle for tactical superiority as the mobile weapon requires ever-increasing upgrades in firepower and armour. The Clausewitzian trinity applies to preparations for war, but also the ongoing impact of unfolding campaigns. The spiral of up-armouring a weapons system connects a society itself with combat. It can be argued, therefore, that there are internal dynamics around the trinity which transcend historical epochs.

\section{Final Thoughts}

This transepochal comparison of the similarities between war elephants and tanks has sought first and foremost to suggest the need for a reconsideration of the way in which the history of the tank has often been framed. In a sense, it has sought to throw a different light on much of the standard literature which generally considers the tank as a breakthrough in military technology, a tendency often directed by the early technical considerations surrounding the design and development of the first machines. ${ }^{104}$ But this perspective has led to the dismissal

\footnotetext{
${ }^{104}$ In a British General Staff document of early 1916, the machines under development were referred to variously as 'the caterpillar cruiser', the 'armoured fort', or 'landships'. TNA, WO 158/831, SECRET. Note on the Position of Landships, 8 January 1916. These names had emerged from some of the initial considerations of the Landships Committee, which had investigated the original idea, 'which adapts the peculiar qualifications of the caterpillar mode of traction to the transport of a species of armoured turret across cultivated and uneven ground'. TNA, WO 158/831, Secretary, Major, General Staff, Experiments Committee, Minute, 16 June 1915.
} 
of the suggestion that parallels can be identified between tank and elephant warfare. Part of the problem has been the claim made by J.F.C. Fuller that there are inherent principles for the conduct of battles, campaigns and wars which do not change throughout history. ${ }^{105}$ While this may or may not be true, it has prevented historians from recognizing that there are specific military phenomena which can be found in different historical epochs which are remarkably similar. It is the identification of clusters of military concepts in separate eras which can lay the basis for transepochal comparative history, providing that approximately similar processes can be found in each era.

If this comparison has considered the evolutionary cycle of one weapons system, whose fate was sealed by the invention of gunpowder, against another still in existence, this is not to say, of course, that there was a point of absolute historical extinction for the war elephant. Its logistic role in war continued, in fact, into the era of the tank. During the First World War, elephants requisitioned from zoos were used on the Western Front and in cities for moving heavy items. ${ }^{106}$ In the fighting in Burma in the Second World War, both the Japanese and the Allies made use of elephants in order to keep their logistic systems functioning in the inhospitable terrain. Even today, the Kachin Independence Army employs elephants for supply purposes in its fight against the government forces in the mountainous Kachin region of Myanmar (formerly Burma) which borders China's southern Yunnan province. ${ }^{107}$ By virtue of the same logic, in the early stages of the Syrian Civil War which broke out in 2011, improvised armoured vehicles reminiscent of those of the early twentieth

\footnotetext{
105 J.F.C. Fuller, The Foundations of the Science of War (London, 1926), esp. pp. 13-16, 208-29.

${ }^{106}$ See here the photograph of an elephant in the charge of German soldiers moving a log in a French town in early 1915, at http://www.oldmagazinearticles.com/WW1_elephants_in_World_War_One-pdf. Elephants were also used for logistics tasks in Germany on the home front in 1917 and 1918, as some photographs indicate. See the photograph of four elephants pulling a heating cauldron through the streets of Berlin in the winter of 1917, at http://theimageworks.com/pub/nn043/animalswwone/ppages/ppage9.html. Both accessed, 23 July 2017.

${ }^{107}$ Kistler, War Elephants, pp. 226-29; Patrick Winn, 'War Elephants Still Exist. But Only in One Forbidding Place', Global Post, 27 February 2017, https://www.pri.org/stories/2017-02-27/war-elephants-still-exist-onlyone-forbidding-place; accessed 29 March 2017.
} 
century could be seen in combat action during the conflict. ${ }^{108}$ So, it should be borne in mind that elements of one type of warfare can continue in one geographical area and cultural region when it has long since ceased in another.

It follows, then, that this comparison raises two fundamental issues for military history, the first relating to the question of end points in specific tactical-technical cycles. In the case of this transepochal comparative exercise, in very broad terms warfare in Western Europe has been compared with warfare in the Mediterranean region. There would, however, be scope for a more global approach in which individual developmental cycles are considered which did not run parallel to one another. Yet while some historians have been quite persistent in their calls for a global approach to military history which rejects 'Westerncentric bias', considering the interaction of military with other social and cultural institutions, they have been rather less specific as to how such studies should be undertaken. ${ }^{109}$ The first step here would be to recast one of the central ideas underpinning Oswald Spengler's Decline of the West (1918), ${ }^{110}$ and consider whether, in military terms, certain civilizations have maintained a form of military-cultural integrity over a significant period of time. Any attempt to write global military history would require some understanding of specific 'warfare regions', when they were founded, and how long they lasted, and what their specific characteristics were. Such an approach challenges one of the arguments of global historians

\footnotetext{
108 John Hall, 'The REAL road warriors. "Mad Max" battle buses and tanks built by Kurdish fighters to repel ISIS soldiers in Syria', Mail Online, 29 September 2014, http://www.dailymail.co.uk/news/article2773452/The-REAL-road-warriors-Mad-Max-battle-buses-tanks-built-Kurdish-fighters-repel-ISIS-soldiersSyria.html; accessed 30 March 2017.

${ }^{109}$ Barton C. Hacker, 'Military Technology and World History: A Reconnaissance', The History Teacher, 30 (August 1997), pp. 461-87; Jeremy Black, Rethinking Military History (London, 2004), pp. 66-103, 232-44; Wayne E. Lee (ed.), Warfare and Culture in World History (New York \& London, 2011), pp. 1-11; and, Stephen Morillo, What is Military History? (Cambridge, 2013), pp. 70-74.

110 Oswald Spengler, Der Untergang des Abendlandes: Umrisse einer Morphologie der Weltgeschichte. Band I: Gestalt und Wirklichkeit (Munich, 1924), pp. 125-51. The reference to Spengler here should not be understood as acceptance of his ideas, but rather as a point of orientation in a long debate over the nature and form of world history, especially around terms such as 'parallel cultural epochs' [gleichzeitiger Geistesepochen].
} 
that a form of global periodization is required to 'enable' the future writing of global history. ${ }^{111}$

The second fundamental issue relates to the implication in histories of military technology that the subject matter is really about invention and turning points caused by the appearance of new weapons. ${ }^{112}$ In fact, the origins of modern military history in English language studies has lain to a great extent in the influence of J.F.C. Fuller in propagating the view that military organizations have been inherently resistant to change. If he had a tendency to universalize individual examples of genuine conservatism, his work chimed well with some of the early and rather misguided post-1945 works of military sociology. Yet, this comparative analysis suggests that historians need to be careful about assuming that 'military innovation' is synonymous with a completely new invention, or that warfare follows a natural 'upward path', driven primarily by new technology.

Summing up, it should be emphasized that a transepochal comparative approach to the history of war is one of the most taxing of analytical exercises. Not only does it present significant challenges given the difficulties associated with comparing phenomena which occur within different historical eras, these can often be located within different social, geographical and cultural contexts. Moreover, a comparison of ancient and modern warfare faces the problem of the lack of reliable knowledge in many areas, including the origin of certain types of military technology. ${ }^{113}$ This said, the comparative study presented here does suggest that strategy in war is governed by its own internal laws, regardless of cultural or

\footnotetext{
${ }^{111}$ See here, Jerry H. Bentley, 'Cross Cultural Interaction and Periodization in World History', American Historical Review, 101 (June 1996), pp. 749-70. The argument here is not to dismiss 'global periodization', but to argue rather that it needs to be supplemented by additional periodization for specific geographical and cultural regions.

${ }^{112}$ For an excellent summary of problematic assumptions surrounding the history of technology, see David Edgerton, 'Innovation, Technology, or History: What is the Historiography of Technology About?' Technology and Culture, 51 (July 2010), pp. 680-97. See also the argument by Jeremy Black that downplaying 'Eurocentricity' requires considering military technology from a global perspective. Ch. 4, 'Qualifying Technology', in Black, Rethinking Military History, pp. 104-27.

${ }^{113}$ Martin van Creveld, Technology and War from 2000 BC to the Present (London, 1991), makes this point in a chapter entitled, 'The Invention of Invention', p. 217.
} 
geographical area, or historical epoch. While any comparison of phenomena in antiquity with later periods faces the challenge of the impossibility of equal levels of accuracy and detail, ${ }^{114}$ the exercise forces the historian of the modern period to reconsider not only existing historiography from a new angle, but also assumptions about the nature of strategy, modernity and innovation. Above all, it encourages greater awareness of the dangers of adopting assumptions of 'linear development' in military history; and, finally, it teaches that the history of technology should, at times, be subordinated to the wider history of strategy.

\footnotetext{
${ }^{114}$ If generalizations about antiquity are not always welcome, this is not to say that they cannot be drawn in the case of warfare in the ancient world. On this subject, see M.I. Finley, 'Generalizations in Ancient History', in Louis Gottschalk (ed.), Generalizations in the Writing of History: A Report of the Committee on Historical Analysis of the Social Science Research Council (Chicago \& London, 1963), pp. 19-35.
} 


\section{Appendix 1: Comparative Table - War Elephants and WWI Tanks}

\begin{tabular}{|c|c|}
\hline \multicolumn{2}{|l|}{ TACTICAL FUNCTIONS } \\
\hline War Elephants & Tanks \\
\hline $\begin{array}{l}\text { Training: necessary for mahout to control elephant in } \\
\text { battle; knowledge of animal required }\end{array}$ & $\begin{array}{l}\text { Training: tank driver required training, together with } \\
\text { other crew members }\end{array}$ \\
\hline $\begin{array}{l}\text { Flexibility: elephants flexibile in combat; they use } \\
\text { their trunks, feet, bulk to crush and tusks to impale }\end{array}$ & $\begin{array}{l}\text { Flexibility: tanks employ cannon and/or machine-gun; } \\
\text { their tracks can crush barbed-wire or troops }\end{array}$ \\
\hline $\begin{array}{l}\text { Survivability: elephants could survive multiple hits by } \\
\text { spears and arrows }\end{array}$ & $\begin{array}{l}\text { Survivability: WWI tanks could survive multiple hits } \\
\text { from infantry small arms }\end{array}$ \\
\hline $\begin{array}{l}\text { Command and control: command elephants employed } \\
\text { in order to better coordinate groups }\end{array}$ & $\begin{array}{l}\text { Command and control: British and French introduced } \\
\text { specially equipped signal tanks in } 1917\end{array}$ \\
\hline $\begin{array}{l}\text { Increase in firepower: gradually more spear-throwers } \\
\text { placed on elephant, archers provided with howdahs }\end{array}$ & $\begin{array}{l}\text { Increase in firepower: quality of machine-guns } \\
\text { improved during WWI; thereafter better main guns }\end{array}$ \\
\hline $\begin{array}{l}\text { Up-armouring process: armour introduced to protect } \\
\text { legs, head and body of elephant }\end{array}$ & $\begin{array}{l}\text { Up-armouring process: tanks increased in armour } \\
\text { during WWI \& after; weak spots reinforced with steel }\end{array}$ \\
\hline \multicolumn{2}{|l|}{ COUNTER-MEASURES } \\
\hline War Elephants & Tanks \\
\hline $\begin{array}{l}\text { Passive defensive measure: caltrops to injure feet of } \\
\text { elephants (difficult for them to free themselves) }\end{array}$ & $\begin{array}{l}\text { Passive defensive measure: Germans used anti-tank } \\
\text { mine against British and French tanks }\end{array}$ \\
\hline $\begin{array}{l}\text { Projectiles: concentrated hail of spears and arrows at } \\
\text { elephants }\end{array}$ & $\begin{array}{l}\text { Projectiles: Germans employed artillery firing over } \\
\text { open sites and Smk ammunition }\end{array}$ \\
\hline $\begin{array}{l}\text { Blinding/disabling: spear-throwers and archers aimed } \\
\text { at eyes of elephants or mahouts }\end{array}$ & $\begin{array}{l}\text { Blinding/disabling: German infantry taught to fire at } \\
\text { vision slits on Allied tanks }\end{array}$ \\
\hline $\begin{array}{l}\text { Attack on vulnerable parts: infantry sought to attack } \\
\text { legs, underbelly, point below eyes }\end{array}$ & $\begin{array}{l}\text { Attack on vulnerable parts: Germans identified } \\
\text { weakest parts of tanks and sought to fire at those }\end{array}$ \\
\hline $\begin{array}{l}\text { Disruption of attack: loud noises to frighten elephants } \\
\text { (trumpets), use of fire, aim to cause a stampede }\end{array}$ & $\begin{array}{l}\text { Disruption of attack: separate tanks from supporting } \\
\text { infantry }\end{array}$ \\
\hline
\end{tabular}

\begin{tabular}{|c|c|}
\hline War Elephants & Tanks \\
\hline $\begin{array}{l}\text { Pre-battle deployment: in centre of army to disrupt } \\
\text { infantry, cause panic, or on flanks to disrupt cavalry }\end{array}$ & $\begin{array}{l}\text { Pre-battle deployment: in large operations led assault } \\
\text { on defensive lines, killed infantry, or exploited gaps }\end{array}$ \\
\hline $\begin{array}{l}\text { Logistics: elephants able to carry many and supplies } \\
\text { overlong distances }\end{array}$ & $\begin{array}{l}\text { Logistics: fighting tanks and supply tanks able to } \\
\text { transport troops, fuel, ammunition and other supplies }\end{array}$ \\
\hline $\begin{array}{l}\text { Pioneer functions: elephants able to lift heavy } \\
\text { equipment, including artillery pieces, and fell trees }\end{array}$ & $\begin{array}{l}\text { Pioneer functions: tanks could flatten obstacles; } \\
\text { specialist vehicles (e.g. bridging) began development }\end{array}$ \\
\hline \multicolumn{2}{|l|}{ STRATEGIC \& SOCIETAL DIMENSIONS } \\
\hline War Elephants & Tanks \\
\hline $\begin{array}{l}\text { Peace treaties: surrender of elephants demanded as } \\
\text { part of peace treaties }\end{array}$ & $\begin{array}{l}\text { Peace treaties: Imperial Germany required to destroy/ } \\
\text { surrender tanks after } 11 / 11 / 1918 \text { \& Versailles Treaty }\end{array}$ \\
\hline $\begin{array}{l}\text { Parades: captured elephants paraded through streets of } \\
\text { cities as a means of celebrating a victory }\end{array}$ & $\begin{array}{l}\text { Parades: Allied victory parades in } 1918 \text { and } 1919 \\
\text { featured tanks as symbol of victory }\end{array}$ \\
\hline $\begin{array}{l}\text { Elite status: special clothing for mahouts and } \\
\text { organisation of elephant corps }\end{array}$ & $\begin{array}{l}\text { Elite status: own distinctive insignia, and emergence } \\
\text { of individual esprit de corps }\end{array}$ \\
\hline $\begin{array}{l}\text { Commemoration: war elephants portrayed on insignia, } \\
\text { coins, vases, floors of Roman villas }\end{array}$ & $\begin{array}{l}\text { Commemoration: WWI saw tank teapots, model tanks, } \\
\text { illustrations in journals, photographs in newspapers }\end{array}$ \\
\hline
\end{tabular}

